OPEN ACCESS

Edited by:

Guido Giordano,

Università degli Studi Roma Tre, Italy

Reviewed by:

Yuri Taran,

National Autonomous University

of Mexico, Mexico

Valerio Acocella,

Università degli Studi Roma Tre, Italy

*Correspondence:

Andrea Luca Rizzo

andrea.rizzo@ingv.it

Specialty section:

This article was submitted to

Volcanology,

a section of the journal

Frontiers in Earth Science

Received: 01 August 2018 Accepted: 12 March 2019

Published: 12 April 2019

Citation:

Rizzo AL, Caracausi A,

Chavagnac V, Nomikou P, Polymenakou PN, Mandalakis $M$, Kotoulas G, Magoulas A, Castillo A, Lampridou D, Marusczak $N$ and Sonke JE (2019) Geochemistry of $\mathrm{CO}_{2}$-Rich Gases Venting From Submarine Volcanism: The Case

of Kolumbo (Hellenic Volcanic Arc, Greece). Front. Earth Sci. 7:60. doi: 10.3389/feart.2019.00060

\section{Geochemistry of $\mathrm{CO}_{2}$-Rich Gases Venting From Submarine Volcanism: The Case of Kolumbo (Hellenic Volcanic Arc, Greece)}

\author{
Andrea Luca Rizzo ${ }^{1 *}$, Antonio Caracausi ${ }^{1}$, Valérie Chavagnac ${ }^{2}$, Paraskevi Nomikou ${ }^{3}$, \\ Paraskevi N. Polymenakou ${ }^{4}$, Manolis Mandalakis ${ }^{4}$, Georgios Kotoulas 4 , \\ Antonios Magoulas ${ }^{4}$, Alain Castillo², Danai Lampridou ${ }^{3}$, Nicolas Marusczak² and \\ Jeroen E. Sonke ${ }^{2}$ \\ ${ }^{1}$ Istituto Nazionale di Geofisica e Vulcanologia, Sezione di Palermo, Palermo, Italy, ${ }^{2}$ Centre National de la Recherche \\ Scientifique, Géosciences Environnement Toulouse, Toulouse, France, ${ }^{3}$ Department of Geology and Geoenvironment, \\ National and Kapodistrian University of Athens, Athens, Greece, ${ }^{4}$ Hellenic Centre for Marine Research, Institute of Marine \\ Biology, Biotechnology and Aquaculture, Heraklion, Greece
}

Studies of submarine hydrothermal systems in Mediterranean Sea are limited to the southern Italian volcanism, while are totally missing in the Aegean. Here, we report on the geochemistry of high-temperature fluids (up to $220^{\circ} \mathrm{C}$ ) venting at $500 \mathrm{~m}$ b.s.l. from the floor of Kolumbo submarine volcano (Hellenic Volcanic Arc, Greece), which is located $7 \mathrm{~km}$ northeast of Santorini Island. Despite the recent unrest at Santorini, Kolumbo submarine volcano is considered more active due to a higher seismicity. Rizzo et al. (2016) investigated the He-isotope composition of gases collected from seven chimneys and showed that are dominated by $\mathrm{CO}_{2}$ (>97\%), with only a small air contamination. Here we provide more-complete chemical data and isotopic compositions of $\mathrm{CO}_{2}$ and $\mathrm{CH}_{4}$, and $\mathrm{Hg}(0)$ concentration. We show that the gases emitted from different vents are fractionated by the partial dissolution of $\mathrm{CO}_{2}$ in water. Fractionation is also evident in the C-isotope composition $\left(\delta^{13} \mathrm{C}_{\mathrm{CO}_{2}}\right)$, which varies between -0.04 and $1.15 \%$. We modeled this process to reconstruct the chemistry and $\delta^{13} \mathrm{C}_{\mathrm{CO}_{2}}$ of intact magmatic gases before fractionation. We argue that the $\mathrm{CO}_{2}$ prior to $\mathrm{CO}_{2}$ dissolution in water had $\delta^{13} \mathrm{C} \sim-0.4 \%$ and $\mathrm{CO}_{2} /{ }^{3} \mathrm{He}$ $\sim 1 \times 10^{10}$. This model reveals that the gases emitted from Kolumbo originate from a homogeneous mantle contaminated with $\mathrm{CO}_{2}$, probably due to decarbonation of subducting limestone, which is similar to other Mediterranean arc volcanoes (e.g., Stromboli, Italy). The isotopic signature of $\mathrm{CH}_{4}\left(\delta^{13} \mathrm{C} \sim-18 \%\right.$ and $\delta \mathrm{D} \sim-117 \%$ ) is within a range of values typically observed for hydrothermal gases (e.g., Panarea and Campi Flegrei, Italy), which is suggestive of mixing between thermogenic and abiotic $\mathrm{CH}_{4}$. We report that the concentrations of $\mathrm{Hg}(0)$ in Kolumbo fluids are particularly high ( 61 to $1300 \mathrm{ng} \mathrm{m}^{-3}$ ) when compared to land-based fumaroles located on Santorini 
and worldwide aerial volcanic emissions. This finding may represent further evidence for the high level of magmatic activity at Kolumbo. Based on the geo-indicators of temperature and pressure, we calculate that the magmatic gases equilibrate within the Kolumbo hydrothermal system at about $270^{\circ} \mathrm{C}$ and at a depth of $\sim 1 \mathrm{~km}$ b.s.l.

Keywords: Hellenic Volcanic Arc, Kolumbo submarine volcano, submarine gases, gas-water interaction, hydrothermal system, $\mathrm{CO}_{2}, \mathrm{CH}_{4}$

\section{INTRODUCTION}

About $80 \%$ of Earth volcanism occurs on the ocean floor (Crisp, 1984), which has greatly hindered the understanding of the natural outgassing of volatiles from the Earth's interior and its impact on the environment. Several submarine volcanoes have been discovered in recent decades, and geochemical studies have investigated the current status of submarine magmatichydrothermal systems. These studies have focused either on midocean ridges (e.g., Butterfield et al., 1990; Lilley et al., 1993; Von Damm, 1995; Von Damm et al., 1995; Lupton et al., 1999) or subduction-related settings (Taran et al., 1992; Tsunogai et al., 1994; Caracausi et al., 2005; Chiodini et al., 2006; Lupton et al., 2006, 2008; Lan et al., 2010; Rizzo et al., 2016; Stucker et al., 2017; and references therein). To the best of our knowledge, Panarea (Aeolian Islands, Italy) is the only volcanic system in the Mediterranean basin characterized by active submarine emissions for which geochemical studies have provided detailed and comprehensive reconstructions of the gas-water interaction process, the origin of gases and the magmatic-hydrothermal system (Caliro et al., 2004; Caracausi et al., 2005 and references therein; Chiodini et al., 2006; Capaccioni et al., 2007; Tassi et al., 2009, 2014; and references therein). The submarine emissions at Panarea are mainly located at relatively shallow water depths (down to $30 \mathrm{~m}$ ), thereby providing easy access for gas sampling.

In 2006, an extensive hydrothermal vent field was discovered at a depth of $500 \mathrm{~m}$ on the floor of Kolumbo submarine crater (Sigurdsson et al., 2006), $7 \mathrm{~km}$ off the northeast coast of the Santorini Island (Figure 1) in the southern Aegean Sea, Greece (Nomikou et al., 2012). Kolumbo volcano lies along the Christianna-Santorini-Kolumbo volcanic line (CSK; Figure 1) that is in the central part of the Hellenic Volcanic Arc (HVA; Nomikou et al., 2016, 2018). The CSK consists of 23 submarine cones and craters (Nomikou et al., 2012; Hooft et al., 2017), of which Kolumbo is the largest and most-active, and last erupted in 1650 (Cantner et al., 2014). The crater is $1.7 \mathrm{~km}$ in diameter and up to $500 \mathrm{~m}$ deep, with the shallowest point nowadays being at $18 \mathrm{~m}$ b.s.l. (below sea level) (Nomikou et al., 2012). All of these volcanoes belong to the modern HVA formed by the subduction of the African plate beneath the European plate (McKenzie, 1972; Le Pichon and Angelier, 1979). HVA began to form 3-4 My ago (Pe-Piper and Piper, 2007), and it stretches from the Gulf of Saronikos in the northwest to the Kos-Nisyros-Yali Islands complex in the east (Figure 1).

The Kolumbo hydrothermal vent field emits $\mathrm{CO}_{2}$-dominated fluids at temperatures as high as $220^{\circ} \mathrm{C}$ (Sigurdsson et al., 2006; Carey et al., 2013) and with a clear mantle origin (Rizzo et al., 2016). However, the origin of $\mathrm{CO}_{2}$ and $\mathrm{CH}_{4}$, the extent of variability in the geochemistry of gases emitted from different chimneys, and the pressure and temperature conditions of the magmatic-hydrothermal system remain unclear.

This study aims to fill this gap in the knowledge by combining the chemical and isotopic data previously reported for noble gases by Rizzo et al. (2016) with new chemical data from the analysis of $\mathrm{Hg}(0)$ and the isotopic compositions of $\mathrm{CO}_{2}$ and $\mathrm{CH}_{4}$. We identified and modeled the main processes underlying the alterations in the isotopic composition of magmatic-hydrothermal fluids along the path of their ascent, in order to reconstruct the original chemistry of these gases at the earliest stages of their formation. Finally, we used geoindicators to elucidate the pressure and temperature conditions of the hydrothermal system feeding the gas vents beneath Kolumbo volcano, and propose a conceptual scheme for the fluid circulation.

\section{PRESENT KNOWLEDGE ABOUT KOLUMBO SUBMARINE VOLCANO}

The Kolumbo submarine volcano developed next to Santorini Island (Figure 1), and several multidisciplinary studies have been carried out over the last decade to shed light on its plumbing system and activity state. The findings of volcanological and geochemical investigations suggest that there are two distinct plumbing systems beneath the Santorini and Kolumbo volcanic systems (Francalanci et al., 2005; Dimitriadis et al., 2009; Kilias et al., 2013). The depth of the magma chamber beneath Kolumbo has been constrained by seismological and petrological observations to lie at depths of 5-7 km (Dimitriadis et al., 2009, 2010; Konstantinou and Yeh, 2012; Cantner et al., 2014). A more recent petrological study revealed striking geochemical differences (e.g., in $\mathrm{Nb} / \mathrm{Yb}, \mathrm{Zr} / \mathrm{Nb},{ }^{206} \mathrm{~Pb} /{ }^{204} \mathrm{~Pb},{ }^{87} \mathrm{Sr} /{ }^{86} \mathrm{Sr}$, and ${ }^{3} \mathrm{He} /{ }^{4} \mathrm{He}$ ) between Kolumbo and Santorini magmas despite their close temporal and spatial associations, supporting the hypothesis that the two magmatic systems have distinct mantle sources (Klaver et al., 2016).

Modern-day microseismicity along the CSK is concentrated beneath Kolumbo at depths of 6-9 km (Bohnhoff et al., 2006; Dimitriadis et al., 2009), with the exception of the unrest at Santorini during 2011-2012 when the seismicity focus migrated within its caldera (e.g., Parks et al., 2012). This confirms that Kolumbo is the most-active volcanic system in the region at the present time (Francalanci et al., 2005; Dimitriadis et al., 2009, 2010; Nomikou et al., 2012; Hubscher et al., 2015). Similar indications come from the presence of intense degassing of hydrothermal vents on the floor of Kolumbo submarine crater 


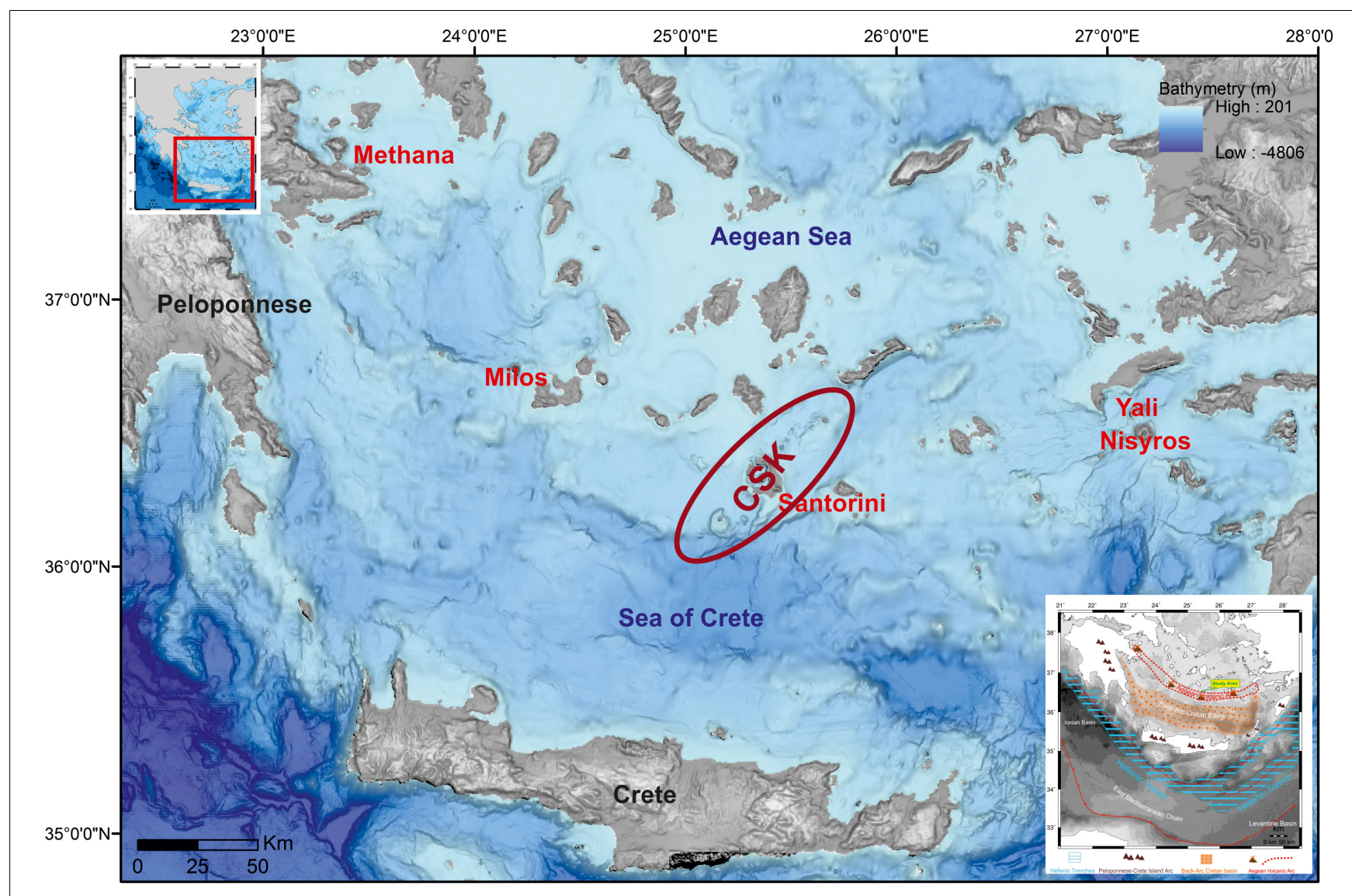

FIGURE 1 | Offshore and onshore topographic map of the Aegean Sea and the location of the main eruptive centers belonging to the modern HVA (Hellenic Volcanic Arc) (modified after Nomikou et al., 2013). Bathymetry is from the EMODNET database (www.emodnet.eu). CSK indicates the Christianna-Santorini-Kolumbo volcanic line. The inset map shows the main geodynamics of the Aegean Sea (Nomikou et al., 2018).

and the geochemistry of these fluids (Sigurdsson et al., 2006; Carey et al., 2013; Rizzo et al., 2016). This intense degassing contrasts with the low-temperature fumaroles observed in the Santorini caldera (Sigurdsson et al., 2006; Rizzo et al., 2015; and references therein).

Sigurdsson et al. (2006) were the first to describe the presence of a widespread hydrothermal vent field on the floor of Kolumbo submarine crater, but only two subsequent geochemical studies have investigated the chemistry of these fluids (Carey et al., 2013; Rizzo et al., 2016). Sigurdsson et al. (2006) and Carey et al. (2013) reported that fluids emitted from the Kolumbo floor are at temperatures up to $220^{\circ} \mathrm{C}$ and $\mathrm{pH} \sim 5$ next to the vents, respectively. Carey et al. (2013) also reported the first data for the chemical composition of gas samples collected from two vents, which indicated that these gases are virtually pure $\mathrm{CO}_{2}$. However, that study focused on the acidification-related hazards that may arise from the dissolution of $\mathrm{CO}_{2}$ in seawater, which was found to occur within the first $10 \mathrm{~m}$ of the water column inside the bowlshaped crater. This dissolution causes local increases in water density and favors the accumulation of $\mathrm{CO}_{2}$-rich, acidic waters at the seafloor that do not permit the growth of macrofauna (Camilli et al., 2015), while additional hazards could arise from the abrupt release of gases at the surface.
Rizzo et al. (2016) reported on ${ }^{3} \mathrm{He} /{ }^{4} \mathrm{He}$ measurements of gas samples collected during May 2014 from seven chimneys. Briefly, they constrained the ${ }^{3} \mathrm{He} /{ }^{4} \mathrm{He}$ signature of Kolumbo gases and of the local mantle at $7.0 \mathrm{Ra}$ (where $\mathrm{Ra}$ is the atmospheric ${ }^{3} \mathrm{He} /{ }^{4} \mathrm{He}$ equal to $1.39 \times 10^{-6}$ ), which is indicative of a MORB-like mantle. It was subsequently revealed that these values are significantly lower than the ${ }^{3} \mathrm{He} /{ }^{4} \mathrm{He}$ values measured in Santorini fluids and rocks ( $\sim \mathrm{Ra}$; Rizzo et al., 2015 and references therein), whereas the observed decrease in the He-isotope signature was attributable to a crustal contamination below the Island. Finally, that study highlighted that ${ }^{3} \mathrm{He} /{ }^{4} \mathrm{He}$ values measured at Kolumbo were the highest ever measured across the entire HAV and indicative of the direct degassing through lithospheric faults.

\section{SAMPLING AND ANALYTICAL TECHNIQUES}

During the 4-SeaBioTech survey on RV AEGAEO (Hellenic Centre for Marine Research) during May 2014, seven chimneys bubbling gas phases with variable sustained fluxes were sampled on the floor of Kolumbo submarine crater with the Greek Max Rover remotely operated vehicle (ROV) (Figure 2). 


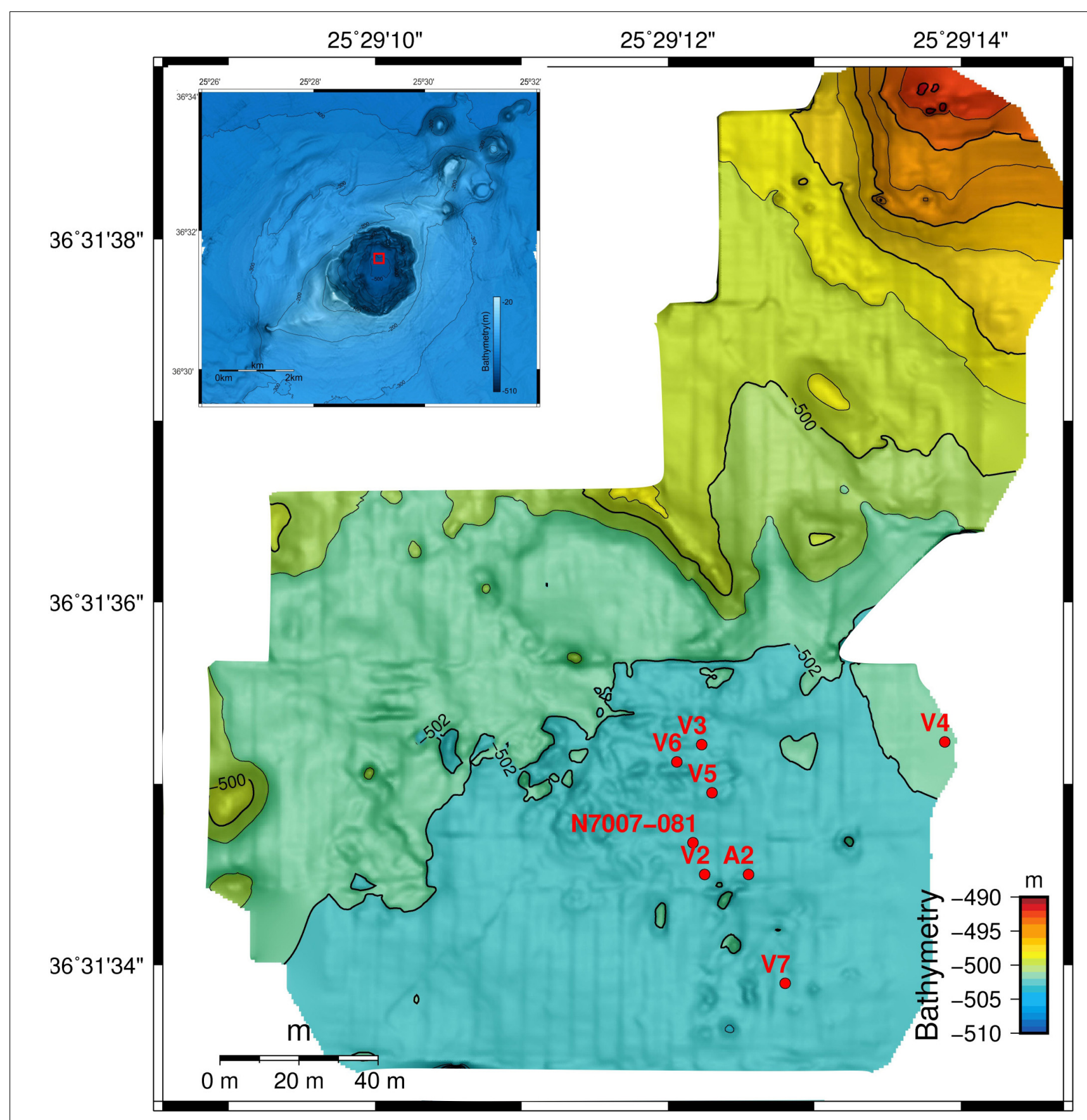

FIGURE 2 | Bathymetric map of the floor of Kolumbo submarine crater and the location of the sampled hydrothermal vents (modified after Kilias et al., 2013). Inset map shows the swathe map of Kolumbo volcano (Rizzo et al., 2016). Red rectangular indicates the location of the vent field.

These chimneys were selected based on a previous seafloor exploration of hydrothermal activity (Sigurdsson et al., 2006; Carey et al., 2013) and a oceanographic survey performed in 2014 (Figure 2). Although direct measurements of temperature were not possible during the 2014 survey, previous surveys found that the fluids discharged in the northern part of the crater floor had temperatures as high as $220^{\circ} \mathrm{C}$, while those present along the northern and eastern margins were no hotter than $70^{\circ} \mathrm{C}$, and characterized by ephemeral bubble fluxes (Sigurdsson et al., 2006; Carey et al., 2013).

The present study collected bubbling hydrothermal gases at the seafloor and stored them in titanium gas-tight bottles equipped with funnels, as described in detail by Rizzo et al. (2016). The obtained gas samples were analyzed in the laboratories of INGV (Istituto Nazionale di Geofisica e Vulcanologia), Sezione di Palermo for their chemistry and 
isotopic compositions of noble gases ( $\mathrm{He}, \mathrm{Ne}$, and $\mathrm{Ar}$ ), $\mathrm{C}$ of $\mathrm{CO}_{2}$, and $\mathrm{C}$ and $\mathrm{H}$ of $\mathrm{CH}_{4}$. The chemical composition of $\mathrm{He}, \mathrm{H}_{2}, \mathrm{O}_{2}$, $\mathrm{N}_{2}, \mathrm{CO}, \mathrm{CH}_{4}$, and $\mathrm{CO}_{2}$ was measured by a gas chromatograph (Clarus 500, Perkin Elmer) equipped with a 3.5-m column (Carboxen 1000) and double detector (hot-wire detector and flame ionization detector [FID]), for which the analytical errors were $<3 \%$. The concentrations of $\mathrm{C}_{2} \mathrm{H}_{6}$ and $\mathrm{C}_{3} \mathrm{H}_{8}$ were also measured in a few selected samples after hydrocarbon enrichment via bubbling pressurized gas in Giggenbach bottles filled with 4-M NaOH (Giggenbach, 1975). Higher hydrocarbons were analyzed using a gas chromatograph (Shimadzu, 2010) equipped with an FID and a capillary column (CP Poraplot) using $\mathrm{He}$ as the carrier gas. The analytical precision for these gas chromatography analyses was better than $5 \%$ for trace gases and $10 \%$ for alkanes.

The $\operatorname{Hg}(0)$ concentration in the gas samples was measured at the Geosciences Environment Toulouse laboratory in France. Titanium canisters filled with hydrothermal gases at a known pressure were connected to a 60-mL impinger (Savillex) via a stainless steel valve, $6 \mathrm{~mm}$ of PTFE tubing and a 6-mm-long Pyrex bubbler tube. The impinger contained $30 \mathrm{~mL}$ of a strongly oxidizing 40 vol\% inverse aqua-regia solution $\left(\mathrm{HNO}_{3}: \mathrm{HCl}=2: 1\right)$. The canister was partly opened, which induced the hydrothermal gases to bubble in the aqua-regia solution and the oxidation of $\mathrm{Hg}(0)$ to $\mathrm{Hg}(\mathrm{II})$. The volume of hydrothermal gas sampled was measured with a ball flowmeter and a chronometer. The flow rate

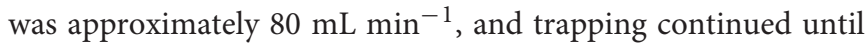
atmospheric pressure equilibration occurred between the canister and the oxidizing solution trap. The total $\mathrm{Hg}$ concentrations were measured in accordance with the USEPA 1631 method. Aliquots of 0.1-1 mL were analyzed in duplicate using semiautomatic cold vapor atomic fluorescence spectrometry (CV-AFS; Brooks Rand Model III, United States) with a single gold trap. The analysis accuracy of CV-AFS was evaluated according to the standard analysis method for the NRC ORMS-4 certified reference material $\left(22.0 \pm 1.6 \mathrm{ng} \mathrm{L}^{-1}\right.$, mean $\left.\pm \mathrm{SD}\right)$, and satisfactory results were obtained $\left(21.3 \pm 2.4 \mathrm{ng} \mathrm{L}^{-1}, n=7\right)$.

The ${ }^{3} \mathrm{He} /{ }^{4} \mathrm{He}$ and ${ }^{4} \mathrm{He} /{ }^{20} \mathrm{Ne}$ ratios addressed in the present study have been reported together with the respective analytical methods by Rizzo et al. (2016). The ${ }^{40} \mathrm{Ar} /{ }^{36} \mathrm{Ar}$ and ${ }^{38} \mathrm{Ar} /{ }^{36} \mathrm{Ar}$ ratios were measured using a mass spectrometer (Argus GVI) with analytical errors of $<0.2 \%$.

The C-isotope composition of $\mathrm{CO}_{2}$ [expressed as $\delta^{13} \mathrm{C} \%$ vs. V-PDB (Vienna-Pee Dee Belemnite)] was determined using a continuous-flow isotope-ratio mass spectrometer (Thermo Delta Plus XP, Finnigan), connected to a gas chromatograph (Trace GC) and interface (Thermo GC/C III, Finnigan). The gas chromatograph and its column (length $=30 \mathrm{~m}$ and i.d. $=0.32 \mathrm{~mm}$; Poraplot-Q) were operated at a constant temperature of $50^{\circ} \mathrm{C}$ using $\mathrm{He}$ as the carrier gas. The analytical errors were $<0.1 \%$. The $\mathrm{C}$ and $\mathrm{H}$ isotopes of $\mathrm{CH}_{4}$ were analyzed using the same instrument. A combustion interface (Thermo GC III, Finnigan) was used to produce $\mathrm{CO}_{2}$ from methane, while a gas-chromatograph/thermal-conversion interface provided online high-temperature conversion of $\mathrm{CH}_{4}$ into $\mathrm{H}$. The SDs for the $\delta^{13} \mathrm{C}$ and $\delta \mathrm{D}$ measurements of $\mathrm{CH}_{4}$ were $<0.2$ and $<2.5 \%$, respectively.

\section{RESULTS}

\section{Gas Chemistry}

The chemical composition of submarine gases collected at Kolumbo is presented in Table 1. These gases are dominated by $\mathrm{CO}_{2}$, which is present at concentrations up to $99.1 \%$ (Figure 3A). The concentration of $\mathrm{CH}_{4}$ ranges from 1052 to $5521 \mathrm{ppm}$, while $\mathrm{C}_{2} \mathrm{H}_{6}$ and $\mathrm{C}_{3} \mathrm{H}_{8}$ exhibit much narrow ranges of 95-128 and 14-20 ppm, respectively (values measured in the Giggenbach bottle; Giggenbach, 1975). He varies between 9 and 40 ppm, while $\mathrm{H}_{2}$ and $\mathrm{CO}$ range from 170 to $716 \mathrm{ppm}$ and from 2 to $7 \mathrm{ppm}$, respectively. The $\mathrm{O}_{2}$ and $\mathrm{N}_{2}$ contents varied depending on the degree of sample contamination by ambient air, with maximum values of 5.1 and $21 \%$, respectively (Figures $3 \mathbf{B}, \mathbf{4 A}$ ). ${ }^{20} \mathrm{Ne}$ ranges between 0.082 and $4.2 \mathrm{ppm}$, while ${ }^{40} \mathrm{Ar}$ ranges between 69 and 834 ppm (Figure 4B). It should be noted that ${ }^{40} \mathrm{Ar}$ was not measured in the sample with the greatest air contamination $\left(\mathrm{O}_{2}=5.1 \%, \mathrm{~N}_{2}=21 \%\right.$, and $\left.{ }^{20} \mathrm{Ne}=4.2 \mathrm{ppm}\right)$. In order to evaluate the extent of air or the presence of air-saturated water (ASW), $\mathrm{O}_{2}$ and Ar are plotted versus ${ }^{20} \mathrm{Ne}$ in Figures 4A,B, respectively. All of the analyzed samples fell along the line representing air rather than ASW, indicating that this contamination is probably due to sampling or extraction procedures. In order to determine the gas composition before air contamination $\left(G_{f}\right)$, data were corrected based on the $\mathrm{O}_{2}$ content measured in each analysis as follows:

$$
G f=\frac{(G s-(G a \times F))}{(1-F)}
$$

where $G s$ is the concentration of the gaseous species measured in the sample (e.g., He), $G a$ is the concentration of the same gaseous species in air (e.g., $\mathrm{He}=5.24 \mathrm{ppm}$ ) and $F$ is the fraction of air calculated from the $\mathrm{O}_{2}$ concentration measured in the sample divided by the atmospheric $\mathrm{O}_{2}$ concentration $(20.947 \%)$. We point out that even assuming that all of the ${ }^{20} \mathrm{Ne}$ or ${ }^{40} \mathrm{Ar}$ measured in our samples is of atmospheric origin (as for $\mathrm{O}_{2}$ ), the recalculated percentages of air contamination would still be comparable. The back-corrected chemical composition of Kolumbo gases is reported in Table 2.

Furthermore, the concentration of gaseous $\mathrm{Hg}(0)$ differed markedly (and significantly) among the seven investigated chimneys, from 61 to $1301 \mathrm{ng} \mathrm{m}^{-3}$ (Table 3).

\section{Isotopic Composition of Gases}

Table 1 reports the isotopic compositions of $\mathrm{CO}_{2}, \mathrm{CH}_{4}$, and $\mathrm{Ar}$ in the analyzed gases. The $\mathrm{C}$-isotope composition $\left({ }^{13} \mathrm{C}_{\mathrm{CO}_{2}}\right)$ varied between -0.04 and $1.15 \%$ V-PDB, whereas increasing ratios were positively correlated with the concentrations of $\mathrm{He}$, $\mathrm{H}_{2}$, $\mathrm{CO}$, and $\mathrm{CH}_{4}$. The $\mathrm{CH}_{4}$-isotope composition varied over a narrow range for both $\mathrm{C}\left(\delta^{13} \mathrm{C}=-18.8\right.$ to $\left.-17.6 \% \mathrm{~V}-\mathrm{PDB}\right)$ and $\mathrm{H}(\delta \mathrm{D}=-118.6$ to $-115.4 \% \mathrm{~V}-\mathrm{SMOW})$.

The ${ }^{3} \mathrm{He} /{ }^{4} \mathrm{He}$ and ${ }^{4} \mathrm{He} /{ }^{20} \mathrm{Ne}$ ratios used in the present study were previously measured and discussed by Rizzo et al. (2016). Here we further measured the Ar-isotope composition, which was found to be close to the values typically encountered in atmospheric air $\left({ }^{40} \mathrm{Ar} /{ }^{36} \mathrm{Ar}=295.5\right.$ and ${ }^{38} \mathrm{Ar} /{ }^{36} \mathrm{Ar}=0.188$; Ozima and Podosek, 1983). ${ }^{40} \mathrm{Ar} /{ }^{36} \mathrm{Ar}$ in hydrothermal gases varies between 296 and 316, while ${ }^{38} \mathrm{Ar} /{ }^{36} \mathrm{Ar}$ is between 0.187 and 0.189 . 
TABLE 1 | Chemical composition of major and minor gaseous components from Kolumbo hydrothermal vents. $\mathrm{Ar} \mathrm{CO}_{2}$, and $\mathrm{CH}_{4}$ isotope ratios are also reported.

\begin{tabular}{|c|c|c|c|c|c|c|c|c|c|c|c|c|c|c|}
\hline Sample & $\begin{array}{c}\text { Depth } \\
\text { (m) }\end{array}$ & Latitude & Longitude & $\begin{array}{c}\mathrm{He} \\
(\mathrm{ppm})\end{array}$ & $\begin{array}{c}\mathrm{Ne} \\
(\mathrm{ppm})\end{array}$ & $\begin{array}{l}{ }^{40} \mathrm{Ar} \\
(\mathrm{ppm})\end{array}$ & $\begin{array}{c}{ }^{36} \mathrm{Ar} \\
\text { (ppm) }\end{array}$ & $\begin{array}{c}\mathrm{H}_{2} \\
(\mathrm{ppm})\end{array}$ & $\mathrm{O}_{2} \%$ & $\mathrm{~N}_{2} \%$ & $\begin{array}{c}\text { Co } \\
(\mathrm{ppm})\end{array}$ & $\begin{array}{c}\mathrm{CH}_{4} \\
\text { (ppm) }\end{array}$ & $\begin{array}{l}\mathrm{C}_{2} \mathrm{H}_{6} \\
\mathrm{ppm}\end{array}$ & $\begin{array}{c}\mathrm{C}_{3} \mathrm{H}_{8} \\
\mathrm{ppm}\end{array}$ \\
\hline A2 & 497 & $36^{\circ} 31.5700^{\prime} \mathrm{N}$ & $25^{\circ} 29.2110^{\prime} \mathrm{E}$ & 24.1 & 0.086 & 100 & 0.323 & 410.7 & 0.17 & 1.1 & 4.2 & 3270.6 & 95 & 14 \\
\hline V2 & 498 & $36^{\circ} 31.5700^{\prime} \mathrm{N}$ & $25^{\circ} 29.2050^{\prime} \mathrm{E}$ & 9.0 & 4.218 & - & - & 169.6 & 5.12 & 21.0 & 2.2 & 1052.2 & - & - \\
\hline V2 & 498 & $36^{\circ} 31.5700^{\prime} \mathrm{N}$ & $25^{\circ} 29.2050^{\prime} \mathrm{E}$ & 15.1 & 1.685 & 834 & 2.823 & 308.6 & 2.11 & 8.6 & 3.3 & 1938.6 & - & - \\
\hline V3 & 498 & $36^{\circ} 31.5843^{\prime} \mathrm{N}$ & $25^{\circ} 29.2046^{\prime} E$ & 26.0 & 0.104 & 76 & 0.241 & 508.8 & 0.10 & 0.9 & 4.6 & 3689.1 & 128 & 18 \\
\hline V4 & 498 & $36^{\circ} 31.5846^{\prime} \mathrm{N}$ & $25^{\circ} 29.2378^{\prime} \mathrm{E}$ & 11.1 & 1.149 & 696 & 2.349 & 193.9 & 1.51 & 6.6 & 2.5 & 1519.4 & - & - \\
\hline V4 & 498 & $36^{\circ} 31.5846^{\prime} \mathrm{N}$ & $25^{\circ} 29.2378^{\prime} \mathrm{E}$ & 26.5 & 0.843 & 455 & 1.526 & 471.5 & 1.10 & 5.1 & 4.3 & 3119.2 & - & - \\
\hline V5 & 500 & $36^{\circ} 31.5790^{\prime} \mathrm{N}$ & $25^{\circ} 29.2060^{\prime} \mathrm{E}$ & 25.3 & 1.389 & 710 & 2.386 & 402.0 & 1.72 & 7.6 & 4.7 & 3391.8 & - & - \\
\hline V5 & 500 & $36^{\circ} 31.5790^{\prime} \mathrm{N}$ & $25^{\circ} 29.2060^{\prime} \mathrm{E}$ & 26.1 & 0.509 & 294 & 0.981 & 464.3 & 0.67 & 3.1 & 4.6 & 3077.5 & - & - \\
\hline V6 & 498 & $36^{\circ} 31.5824^{\prime} \mathrm{N}$ & $25^{\circ} 29.2012^{\prime} \mathrm{E}$ & 19.8 & 0.082 & 69 & 0.222 & 405.9 & 0.00 & 0.6 & 2.1 & 2848.2 & 118 & 20 \\
\hline V7 & 498 & $36^{\circ} 31.5580^{\prime} \mathrm{N}$ & $25^{\circ} 29.2160^{\prime} \mathrm{E}$ & 39.5 & 0.291 & 182 & 0.590 & 716.4 & 0.17 & 1.3 & 7.1 & 5521.5 & 100 & 15 \\
\hline NA007-081* & 502 & $36^{\circ} 31.5735^{\prime} \mathrm{N}$ & $25^{\circ} 29.2034^{\prime} \mathrm{E}$ & 24.4 & 0.025 & - & - & 400.0 & 0.01 & 0.3 & b.d.l. & 2699.9 & - & - \\
\hline NA007-009* & 502 & $36^{\circ} 31.6059^{\prime} \mathrm{N}$ & $25^{\circ} 29.1969^{\prime} \mathrm{E}$ & - & - & - & - & 299.9 & 0.01 & 0.2 & b.d.l. & 2598.7 & - & - \\
\hline ASSW & & & & 2.3 & 9.7 & 15936 & & & 34.30 & 62.6 & 0.2 & 3.8 & & \\
\hline AIR & & & & 5.24 & 16.48 & 9300 & 31.5 & 0.53 & 20.95 & 78.084 & 0.25 & 1.7 & & \\
\hline
\end{tabular}

TABLE 1 | Continued

\begin{tabular}{|c|c|c|c|c|c|c|c|c|c|c|c|c|}
\hline Sample & $C_{1} /\left(C_{2}+C_{3}\right)$ & $\mathrm{CO}_{2} \%$ & F Air & ${ }^{40} \mathrm{Ar} /{ }^{36} \mathrm{Ar}$ & $\operatorname{Err}_{40 / 36}+/-$ & ${ }^{38} \mathrm{Ar} /{ }^{36} \mathrm{Ar}$ & $\operatorname{Err}_{38 / 36}+1-$ & $\begin{array}{l}{ }^{40} \mathrm{Ar}^{*} \\
\text { (ppm) }\end{array}$ & ${ }^{4} \mathrm{He} /{ }^{40} \mathrm{Ar}^{*}$ & $\begin{array}{c}\delta^{13} \mathrm{C}_{\mathrm{CO}_{2}} \% 0 \\
\text { vs. PDB }\end{array}$ & $\begin{array}{c}\delta^{13} \mathrm{C}-\mathrm{CH}_{4} \% 0 \\
\text { vs. PDB }\end{array}$ & $\begin{array}{l}\delta \mathrm{D}-\mathrm{CH}_{4} \% 0 \\
\text { vs. SMOW }\end{array}$ \\
\hline $\mathrm{A} 2$ & 1817 & 98.4 & 0.0081 & 310.2 & 0.052 & 0.1880 & 0.0001 & 4.8 & 5.0 & 0.60 & -17.6 & -115.4 \\
\hline V2 & - & 73.8 & 0.2443 & - & - & - & - & - & - & -0.04 & - & - \\
\hline V2 & - & 89.1 & 0.1006 & 296.0 & 0.051 & 0.1870 & 0.0001 & - & - & - & - & - \\
\hline V3 & 1699 & 98.6 & 0.0048 & 315.9 & 0.060 & 0.1878 & 0.0001 & 5.0 & 5.3 & 0.75 & -18.8 & -116 \\
\hline V4 & - & 91.7 & 0.0723 & 296.0 & 0.065 & 0.1879 & 0.0001 & - & - & -0.03 & - & - \\
\hline V4 & - & 93.4 & 0.0526 & 298.1 & 0.043 & 0.1872 & 0.0001 & - & - & - & - & - \\
\hline V5 & - & 90.3 & 0.0820 & 297.4 & 0.051 & 0.1891 & 0.0001 & - & - & 0.63 & - & - \\
\hline V5 & - & 95.9 & 0.0321 & 299.3 & 0.065 & 0.1876 & 0.0002 & - & - & 0.63 & - & - \\
\hline V6 & 1964 & 99.1 & 0.0000 & 311.6 & 0.059 & 0.1876 & 0.0001 & 3.6 & 5.5 & 0.46 & -18.1 & -118.6 \\
\hline V7 & 1948 & 97.9 & 0.0082 & 308.9 & 0.069 & 0.1875 & 0.0002 & 8.1 & 4.8 & 1.15 & - & - \\
\hline NA007-081* & - & 99.4 & 0.0005 & - & - & - & - & - & - & - & - & - \\
\hline NA007-009* & - & 99.5 & 0.0005 & - & - & - & - & - & - & - & - & - \\
\hline ASSW & & 1.4 & 1 & & & & & & & & & \\
\hline AIR & & 0.038 & 1 & 295.5 & & 0.188 & & & & -8 & & \\
\hline
\end{tabular}

$\mathrm{C}_{2} \mathrm{H}_{6}$ and $\mathrm{C}_{3} \mathrm{H}_{8}$ were measured in Giggenbach bottles and then recalculated to the dry gas. * Sample from Carey et al. (2013). b.d.I., below detection limit. -, not determined.

However, ${ }^{40} \mathrm{Ar}$ was corrected for atmospheric contamination $\left({ }^{40} \mathrm{Ar}^{*}\right)$ in the samples having ${ }^{40} \mathrm{Ar} /{ }^{36} \mathrm{Ar}>308$ as follows:

$$
{ }^{40} \mathrm{Ar}^{*}={ }^{40} \mathrm{Ar}_{\text {sample }}-\left[{ }^{36} \mathrm{Ar}_{\text {sample }} \cdot\left({ }^{40} \mathrm{Ar} /{ }^{36} \mathrm{Ar}\right) \text { air }\right]
$$

This correction is useful for obtaining accurate estimates of the ${ }^{4} \mathrm{He} /{ }^{40} \mathrm{Ar}^{*}$ ratio, which in Kolumbo gases vary between 4.8 and 5.5. These ratios are within the ratio range typical of the mantle $\left({ }^{4} \mathrm{He} /{ }^{40} \mathrm{Ar}=1-5\right.$; e.g., Ozima and Podosek, 1983; Marty, 2012), confirming that Kolumbo gases preserve the features that they have inherited from the magma.

\section{DISCUSSION}

\section{Gas-Water Interaction of Magmatic Fluids}

The chemical composition of gases corrected for air contamination as well as the $\delta^{13} \mathrm{C}_{\mathrm{CO}_{2}}$ show a variability clearly modulated by a process of selective dissolution of gases in water driven by their different solubilities (Figures 5, 6). In order to determine the original composition of the intact gases, which is necessary for evaluating the origin of $\mathrm{CO}_{2}$ and the pressure and temperature conditions of the hydrothermal system, we initially defined the boundary conditions for modeling. Due to the lack of direct measures of temperature in the fluids discharged from the Kolumbo chimneys, we assumed a homogeneous emission temperature of $220^{\circ} \mathrm{C}$, as measured by Sigurdsson et al. (2006) (see section "Sampling and Analytical Techniques"). This assumption is reasonable because it is based on direct measurements made in the same part of the floor of Kolumbo submarine crater and from vents showing a sustained flux of gas bubbles, which indicates the concomitant release of high-temperature fluids (Sigurdsson et al., 2006). Regardless of the accuracy of this estimate, it should be remembered that any slight difference in temperature between vents would mostly influence the extent of the $\mathrm{CO}_{2}$ dissolution in water rather than the path of fractionation of less-soluble species, especially when 


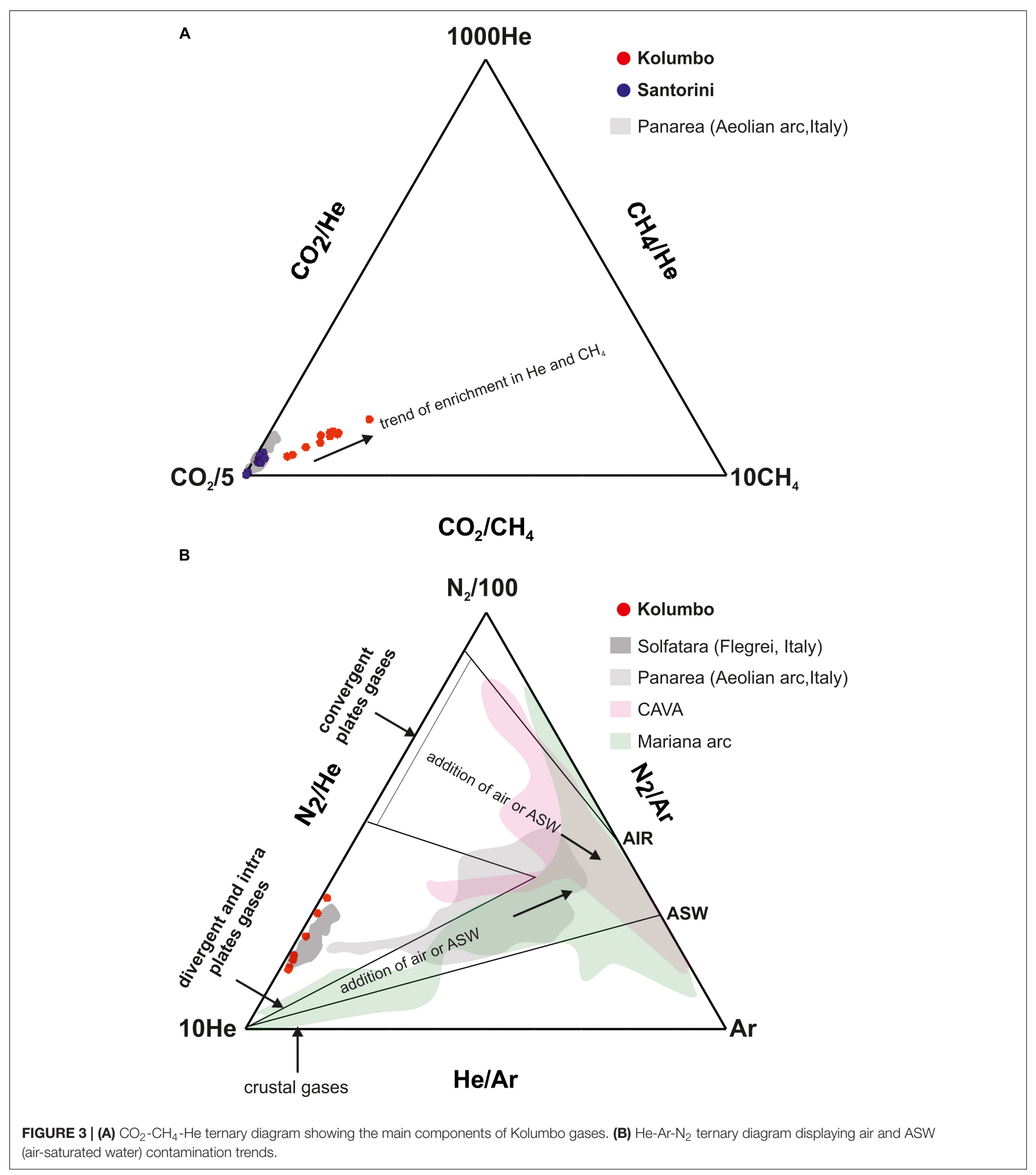

considering elemental ratios. Since gases are emitted on the floor of Kolumbo submarine crater, which is at around $500 \mathrm{~m}$ b.s.l., we assumed a constant pressure of 50 bar. Based on the assumption of a temperature of $220^{\circ} \mathrm{C}$, the saturated vapor pressure would be $\sim 23$ bar. This means that the partial pressure of $\mathrm{CO}_{2}$ would be $\sim 27$ bar within a bubble of fluids exsolved from the vents located at the hydrostatic pressure of 50 bar.

Considering that we are dealing with submarine emissions, it is reasonable to assume that hydrothermal water condenses in the seawater together with the highly soluble acidic gases 


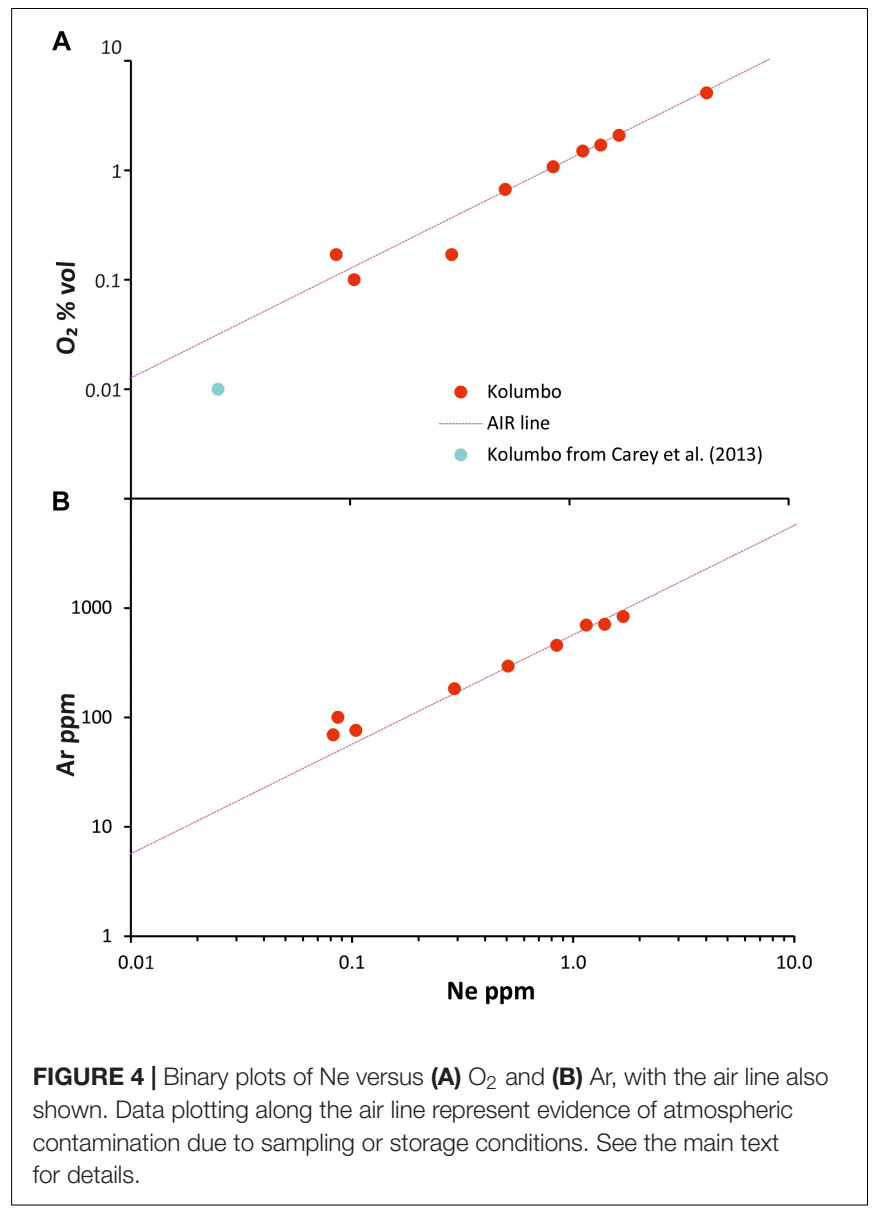

$\left(\mathrm{SO}_{2}, \mathrm{HCl}\right.$, and $\left.\mathrm{HBr}\right)$. We cannot exclude that the $\mathrm{CO}_{2}$ continued to dissolve in water inside the gas-tight bottles during the time that lapsed between sampling and gas extraction aboard the vessel, mostly because of cooling.
The residual gas phase that we studied comprised mainly $\mathrm{CO}_{2}$ and secondarily $\mathrm{N}_{2}, \mathrm{H}_{2}, \mathrm{CO}$ and $\mathrm{CH}_{4}$, as well as noble gases at low levels and trace gases. We ultimately assumed a geochemical system comprising $\mathrm{CO}_{2}, \mathrm{~N}_{2}, \mathrm{H}_{2}, \mathrm{CO}$, $\mathrm{CH}_{4}, \mathrm{He}, \mathrm{Ne}$ and $\mathrm{Ar}$, all of which dissolve in liquid water according to Henry's law. After the condensation of water vapors and highly soluble acidic gases, a further progression of gas dissolution would induce the preferential dissolution of $\mathrm{CO}_{2}$ in water and the consequent enrichment of less-soluble species such as $\mathrm{N}_{2}, \mathrm{H}_{2}, \mathrm{CO}$, hydrocarbons and noble gases (Sander, 2015). Since our dry gas mixture comprised > 97\% $\mathrm{CO}_{2}$, we deduce that the extent of fractionation was low. Therefore, this process can be better evaluated using other components such as $\mathrm{CH}_{4}$ versus $\mathrm{He}$ (Figures 5, 6) rather than the $\mathrm{CO}_{2}$ concentration.

Following the thermodynamic approach proposed by Fernandez-Prini et al. (2003 and references therein) and based on our pressure and temperature boundary conditions, we calculated Henry's constant $k_{\mathrm{H}}$ and the gas-liquid distribution constant $K_{\mathrm{D}}$ for each species included in our geochemical system. We simulated a condensation process under equilibrium conditions as expressed by the Rayleigh (1896) equation:

$$
\frac{R v}{R v_{0}}=f^{\alpha-1}
$$

where $R v_{0}$ is the initial ratio of the bulk composition (e.g., $\left.\mathrm{He} / \mathrm{CO}_{2}\right), R v$ is the same instantaneous ratio in the residual gas phase $(v), f$ is the fraction of the residual gas phase and $\alpha$ is the fractionation factor determined by the solubility ratio of the species under consideration (e.g., $k_{\mathrm{H}-\mathrm{He}} / k_{\mathrm{H}-\mathrm{CO}_{2}}$ ). We also assumed open-system conditions considering the continuous removal of gas-saturated parcels of water.

The initial composition applied in our model is reported in Table 2 and in the captions of Figures 5-7. Similarly to gas levels, the isotopic composition of gaseous $\mathrm{CO}_{2}\left({ }^{13} \mathrm{C}_{\mathrm{CO}_{2}}\right)$ changes as a result of its dissolution in water (Figure 7) and the

TABLE 2 | Restored chemical composition after correction for atmospheric contamination and pristine composition of gases after correction for $\mathrm{CO}_{2}$ dissolution in water.

\begin{tabular}{|c|c|c|c|c|c|c|c|c|c|c|c|c|}
\hline Sample & $\begin{array}{c}\text { Depth } \\
\text { (m) }\end{array}$ & Latitude & Longitude & $\begin{array}{l}\mathrm{He} \\
(\mathrm{ppm})\end{array}$ & $\begin{array}{c}\mathrm{H}_{2} \\
\text { (ppm) }\end{array}$ & $\mathrm{N}_{2} \%$ & $\begin{array}{c}\text { CO } \\
(\mathrm{ppm})\end{array}$ & $\begin{array}{l}\mathrm{CH}_{4} \\
(\mathrm{ppm})\end{array}$ & $\mathrm{CO}_{2} \%$ & $\mathrm{He} / \mathrm{CO}_{2}$ & $\mathrm{CH}_{4} / \mathrm{CO}_{2}$ & $\mathrm{CO}_{2} / 3 \mathrm{He}^{\wedge}$ \\
\hline $\mathrm{A} 2$ & 497 & $36^{\circ} 31.5700^{\prime} \mathrm{N}$ & $25^{\circ} 29.2110^{\prime} \mathrm{E}$ & 24.3 & 414.0 & 0.4 & 4.2 & 3297.2 & 99.2 & $2.44 \mathrm{E}-05$ & 3.32E-03 & $4.19 E+09$ \\
\hline V2 & 498 & $36^{\circ} 31.5700^{\prime} \mathrm{N}$ & $25^{\circ} 29.2050^{\prime} \mathrm{E}$ & 10.2 & 223.6 & 2.5 & 2.8 & 1387.7 & 97.3 & $1.05 E-05$ & $1.43 E-03$ & $9.78 \mathrm{E}+09$ \\
\hline V2 & 498 & $36^{\circ} 31.5700^{\prime} \mathrm{N}$ & $25^{\circ} 29.2050^{\prime} \mathrm{E}$ & 16.2 & 342.8 & 0.8 & 3.7 & 2153.1 & 98.9 & 1.64E-05 & $2.18 \mathrm{E}-03$ & $6.22 \mathrm{E}+09$ \\
\hline V3 & 498 & $36^{\circ} 31.5843^{\prime} \mathrm{N}$ & $25^{\circ} 29.2046^{\prime} E$ & 26.1 & 511.2 & 0.5 & 4.6 & 3706.7 & 99.0 & 2.64E-05 & $3.74 \mathrm{E}-03$ & $3.87 E+09$ \\
\hline V4 & 498 & $36^{\circ} 31.5846^{\prime} \mathrm{N}$ & $25^{\circ} 29.2378^{\prime} \mathrm{E}$ & 11.6 & 208.8 & 1.0 & 2.7 & 1636.5 & 98.8 & 1.17E-05 & 1.66E-03 & $8.79 E+09$ \\
\hline V4 & 498 & $36^{\circ} 31.5846^{\prime} \mathrm{N}$ & $25^{\circ} 29.2378^{\prime} \mathrm{E}$ & 27.7 & 497.5 & 1.1 & 4.5 & 3290.6 & 98.5 & 2.81E-05 & 3.34E-03 & $3.63 E+09$ \\
\hline V5 & 500 & $36^{\circ} 31.5790^{\prime} \mathrm{N}$ & $25^{\circ} 29.2060^{\prime} \mathrm{E}$ & 27.0 & 437.5 & 1.3 & 5.1 & 3691.4 & 98.3 & $2.75 E-05$ & 3.76E-03 & $3.72 E+09$ \\
\hline V5 & 500 & $36^{\circ} 31.5790^{\prime} \mathrm{N}$ & $25^{\circ} 29.2060^{\prime} \mathrm{E}$ & 26.8 & 479.6 & 0.6 & 4.8 & 3178.7 & 99.0 & $2.71 E-05$ & $3.21 \mathrm{E}-03$ & $3.74 \mathrm{E}+09$ \\
\hline V6 & 498 & $36^{\circ} 31.5824^{\prime} \mathrm{N}$ & $25^{\circ} 29.2012^{\prime} \mathrm{E}$ & 19.8 & 405.9 & 0.6 & 2.1 & 2848.2 & 99.1 & 2.00E-05 & 2.87E-03 & $5.13 E+09$ \\
\hline V7 & 498 & $36^{\circ} 31.5580^{\prime} \mathrm{N}$ & $25^{\circ} 29.2160^{\prime} \mathrm{E}$ & 39.7 & 722.3 & 0.7 & 7.1 & 5566.8 & 98.7 & 403E-05 & 5.64E-03 & $2.55 E+09$ \\
\hline NA007-081* & 502 & $36^{\circ} 31.5735^{\prime} \mathrm{N}$ & $25^{\circ} 29.2034^{\prime} \mathrm{E}$ & 24.4 & 400.2 & 0.2 & - & 2701.2 & 99.4 & $2.45 E-05$ & $2.72 \mathrm{E}-03$ & $4.29 E+09$ \\
\hline NA007-009* & 502 & $36^{\circ} 31.6059^{\prime} \mathrm{N}$ & $25^{\circ} 29.1969^{\prime} \mathrm{E}$ & - & 300.0 & 0.2 & - & 2599.9 & 99.5 & - & $2.61 \mathrm{E}-03$ & - \\
\hline \multicolumn{4}{|c|}{ Pristine composition of gases before $\mathrm{CO}_{2}$ dissolution in water } & 8 & 150 & 0.2 & 1.5 & 1150 & 99.8 & 8.02E-06 & 1.15E-03 & $1.26 \mathrm{E}+10$ \\
\hline
\end{tabular}

* Sample from Carey et al. (2013). ${ }^{\wedge 3}$ He from Rizzo et al. (2016). 
TABLE 3 | Hydrothermal gas $\mathrm{Hg}(0)$ concentrations of the seven chimneys where it was possible to make measurements.

\begin{tabular}{lcccc}
\hline Sample & $\begin{array}{c}\text { Depth } \\
\mathbf{( m )}\end{array}$ & Latitude & Longitude & $\begin{array}{c}\text { Hg0 concentration } \\
\text { (canister) } \mathbf{( n g} / \mathbf{m}^{\mathbf{3}} \text { ) }\end{array}$ \\
\hline A2 & 497 & $36^{\circ} 31.5700^{\prime} \mathrm{N}$ & $25^{\circ} 29.2110^{\prime} \mathrm{E}$ & 61 \\
V1 & 498 & $36^{\circ} 31.5700^{\prime} \mathrm{N}$ & $25^{\circ} 29.2050^{\prime} \mathrm{E}$ & 1301 \\
V2 & 498 & $36^{\circ} 31.5700^{\prime} \mathrm{N}$ & $25^{\circ} 29.2050^{\prime} \mathrm{E}$ & 612 \\
V3 & 498 & $36^{\circ} 31.5843^{\prime} \mathrm{N}$ & $25^{\circ} 29.2046^{\prime} \mathrm{E}$ & 153 \\
V5 & 500 & $36^{\circ} 31.5790^{\prime} \mathrm{N}$ & $25^{\circ} 29.2060^{\prime} \mathrm{E}$ & 73 \\
V6 & 498 & $36^{\circ} 31.5824^{\prime} \mathrm{N}$ & $25^{\circ} 29.2012^{\prime} \mathrm{E}$ & 84 \\
V7 & 498 & $36^{\circ} 31.5580^{\prime} \mathrm{N}$ & $25^{\circ} 29.2160^{\prime} \mathrm{E}$ & 819 \\
\hline
\end{tabular}

isotopic fractionation between gaseous and dissolved inorganic $\mathrm{CO}_{2}\left[\mathrm{CO}_{2}(\mathrm{aq})\right] . \mathrm{CO}_{2}(\mathrm{aq})$ is referred to as dissolved inorganic $\mathrm{C}$ (DIC) and is equal to the sum of the aqueous species $\mathrm{H}_{2} \mathrm{CO}_{3}$, $\mathrm{HCO}_{3}^{-}$, and $\mathrm{CO}_{3}^{2-}$. The fractionation process is modeled using the Rayleigh equation as follows (Clark and Fritz, 1997):

$$
\delta^{13} \mathrm{C}_{\mathrm{CO}_{2}}=\left(\delta^{13} \mathrm{C}_{\mathrm{CO}_{2}}\right)_{0}+\varepsilon \ln (f)
$$

where $\left(\delta^{13} \mathrm{C}_{\mathrm{CO}_{2}}\right)_{0}$ is the initial $\mathrm{CO}_{2}$-isotope composition, $f$ is the fraction of the residual gas phase, and $\varepsilon$ is the fractionation factor between DIC and gaseous $\mathrm{CO}_{2}\left(\mathrm{CO}_{2}(\mathrm{~g})\right)$. This fractionation factor is obtained by summing up the fractionation factors of dissolved $\mathrm{C}$ species and $\mathrm{CO}_{2}$ (g) weighted for their molar fraction with respect DIC (Zhang et al., 1995; Allègre, 2008):

$$
\begin{aligned}
& \varepsilon_{\mathrm{DIC}-\mathrm{CO}_{2}(\mathrm{~g})}=+\left[\mathrm{CO}_{3}^{2-}\right] \varepsilon_{\mathrm{CO}_{3}^{2-}-\mathrm{CO}_{2}(\mathrm{~g})} \\
& {\left[\mathrm{H}_{2} \mathrm{CO}_{3}\right]+\left[\mathrm{HCO}_{3}^{-}\right]+\left[\mathrm{CO}_{3}^{2-}\right] }
\end{aligned}
$$

The molar fraction of each $\mathrm{C}$ species depends on the water temperature and $\mathrm{pH}$. We calculated each fractionation factor at $220^{\circ} \mathrm{C}$ based on the approach of Zhang et al. (1995), while the molar fractions of $\mathrm{H}_{2} \mathrm{CO}_{3}$ and $\mathrm{HCO}_{3}^{-}$were set to 0.96 and 0.04 , respectively. We also assumed that the molar fraction of $\mathrm{CO}_{3}^{2-}$ was 0 given that the $\mathrm{pH}$ of water on the floor of Kolumbo submarine crater is typically lower than 8 (Mandalakis et al., 2019), which means that the terms involving $\left[\mathrm{CO}_{3}^{2-}\right]$ can be neglected in the above equation. Under these conditions,

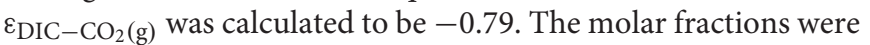
also used in the following equation describing the dissociation of $\mathrm{H}_{2} \mathrm{CO}_{3}$ in order to estimate the $\mathrm{pH}$ of water in which $\mathrm{CO}_{2}$ was dissolved:

$$
\begin{gathered}
\mathrm{H}_{2} \mathrm{CO}_{3(\mathrm{aq})} \leftrightarrow \mathrm{H}_{\mathrm{aq}}^{+}+\mathrm{HCO}_{3(\mathrm{aq})}^{-} \\
\mathrm{K}_{\mathrm{A} 1}=\frac{\left[\mathrm{HCO}_{3}^{-}\right]\left[\mathrm{H}^{+}\right]}{\left[\mathrm{H}_{2} \mathrm{CO}_{3}\right]}=4.3 \cdot 10^{-7}
\end{gathered}
$$
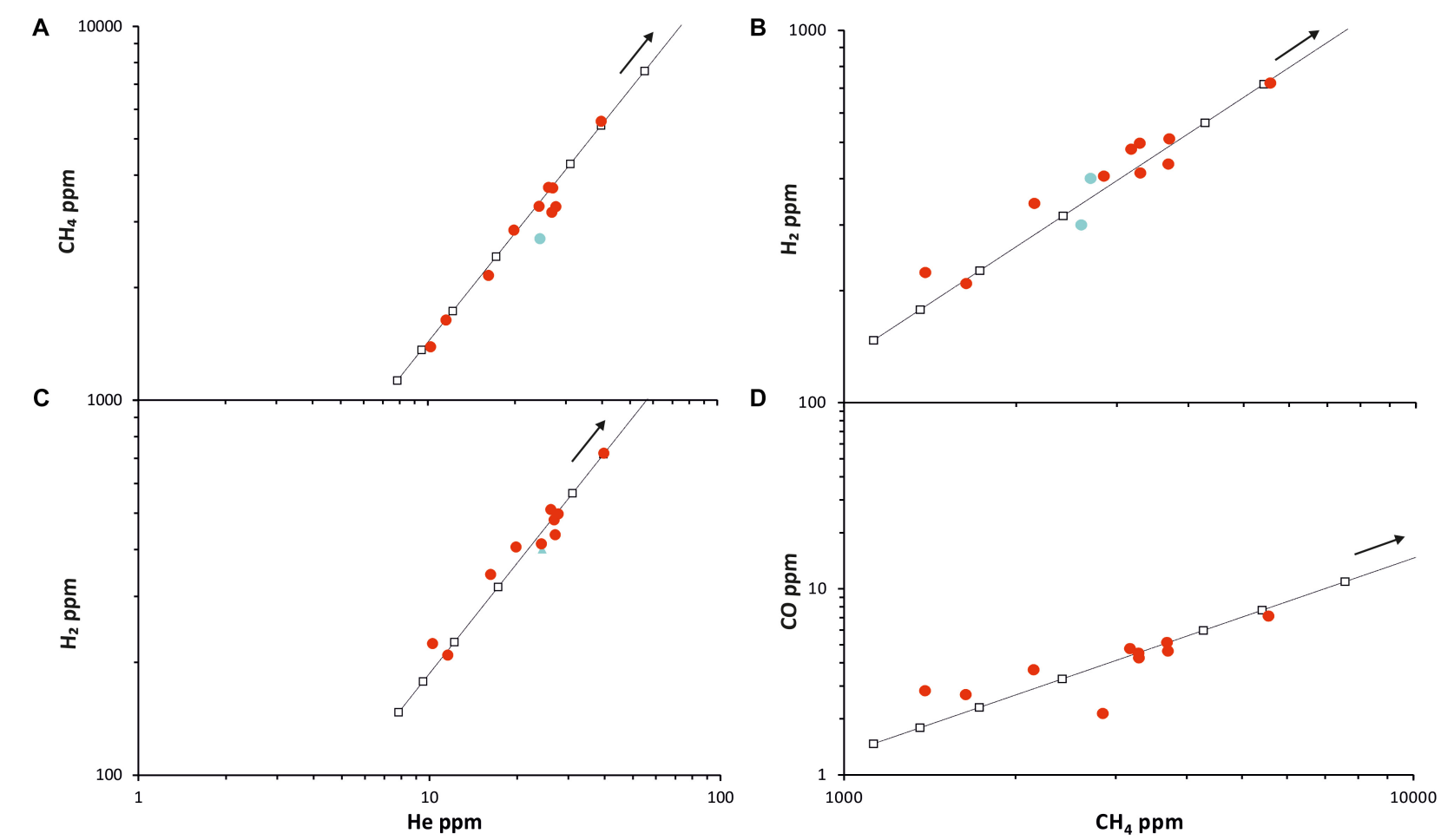

FIGURE 5 | Plots of He versus (A) $\mathrm{CH}_{4}$ and (B) $\mathrm{H}_{2}$, and $\mathrm{CH}_{4}$ versus (C) $\mathrm{H}_{2}$ and (D) $\mathrm{CO}$. Legend symbols as in Figure 4. Lines show the path of selective dissolution of gases in water modeled as an open-system condensation process under equilibrium conditions. Arrows indicate the process direction. The starting gas composition for modeling was $\mathrm{He}=8 \mathrm{ppm}, \mathrm{H}_{2}=150 \mathrm{ppm}, \mathrm{N}_{2}=0.2 \%, \mathrm{CH}_{4}=1150 \mathrm{ppm}, \mathrm{CO}=1.5 \mathrm{ppm}$ and $\mathrm{CO}_{2}=99.8 \%$. See the main text and Table 2 for further details. 


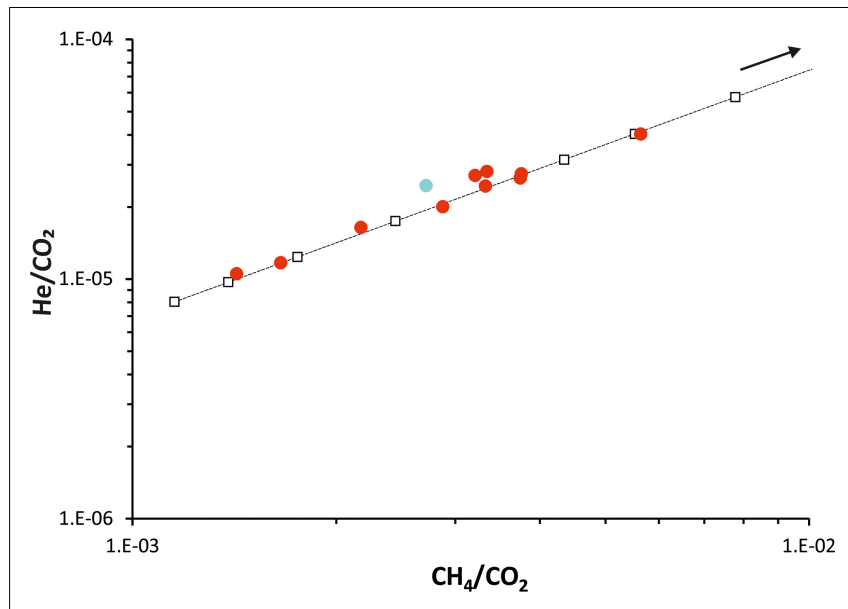

FIGURE 6 | Plot of $\mathrm{CH}_{4} / \mathrm{CO}_{2}$ versus $\mathrm{He} / \mathrm{CO}_{2}$. Legend symbols as in Figure 4. Line and arrow are as in Figure 5. The starting gas composition for modeling was $\mathrm{CH}_{4} / \mathrm{CO}_{2}=1.15 \times 10^{-3}$ and $\mathrm{He} / \mathrm{CO}_{2}=8.02 \times 10^{-6}$. See the main text for further details.

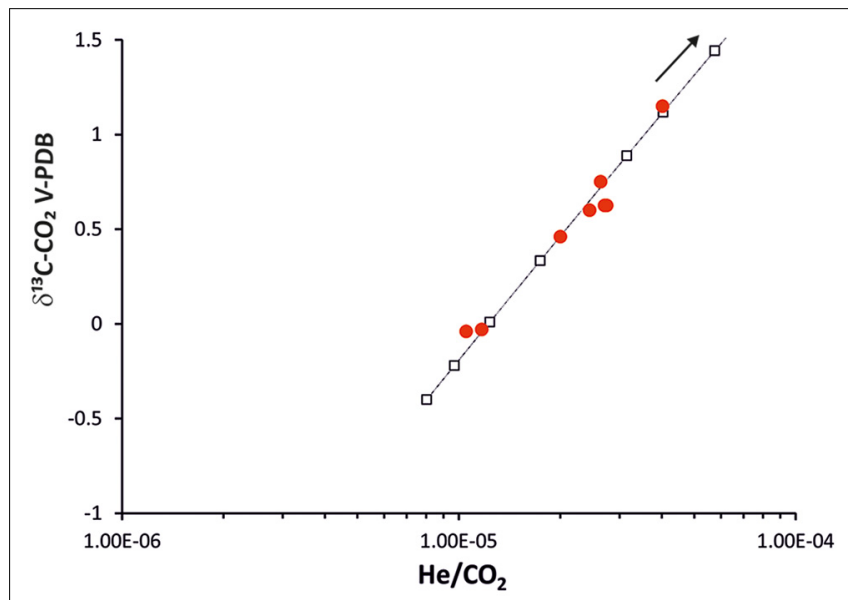

FIGURE 7 | Plot of $\mathrm{He} / \mathrm{CO}_{2}$ versus $\delta^{13} \mathrm{C}_{\mathrm{CO}_{2}}$. Legend symbols as in Figure 4. Line and arrow are as in Figure 5. The starting gas composition for modeling was $\delta^{13} \mathrm{C}_{\mathrm{CO}_{2}}=-0.4 \%$ and $\mathrm{He} / \mathrm{CO}_{2}=8.02 \times 10^{-6} \cdot \varepsilon_{\mathrm{DIC}-\mathrm{CO}_{2} \mathrm{~g}}=-0.79$ at $220^{\circ} \mathrm{C}$, which implies $\mathrm{H}_{2} \mathrm{CO}_{3}$ and $\mathrm{HCO}_{3}^{-}$molar fractions of 0.96 and 0.04 , respectively, equivalent to $\mathrm{pH}=5$. See the main text for further details.

The chemical and $\delta^{13} \mathrm{C}_{\mathrm{CO}_{2}}$ variability of gases emitted from Kolumbo (Figures 7, 8) is well-modeled by a trend of $\mathrm{CO}_{2}$ dissolution in water having $\mathrm{H}_{2} \mathrm{CO}_{3}$ and $\mathrm{HCO}_{3}^{-}$molar fractions of 0.96 and 0.04 , respectively, which at $220^{\circ} \mathrm{C}$ corresponds to $\mathrm{pH}$ $\sim 5$. It is particularly interesting that this value is identical to that measured by Carey et al. (2013) in fluids emitted by a neighboring vent on the floor of Kolumbo submarine crater thereby further validating the boundary conditions selected for our model.

\section{Origin of Gases Emitted at Kolumbo Origin of $\mathrm{CO}_{2}$}

Back-corrected calculations of the concentration and isotopic composition of gaseous $\mathrm{CO}_{2}$ before its selective dissolution in water allow evaluation of its origin in the Kolumbo magmatic system and the making of inferences about the local mantle. To our knowledge, this is the first study to provide data on $\delta^{13} \mathrm{C}_{\mathrm{CO}_{2}}$ emitted by Kolumbo submarine volcano.

We examined the origin of $\mathrm{CO}_{2}$ by combining the ${ }^{3} \mathrm{He} /{ }^{4} \mathrm{He}$ values reported by Rizzo et al. (2016) with the $\mathrm{CO}_{2}$ concentration and $\delta^{13} \mathrm{C}_{\mathrm{CO}_{2}}$ values measured in the present study. The plot of $\delta^{13} \mathrm{C}_{\mathrm{CO}_{2}}$ versus $\mathrm{CO}_{2} /{ }^{3} \mathrm{He}$ is a convenient diagnostic for this purpose (Sano and Marty, 1995), although post-magmatic processes may strongly modify the original gas composition and thus compromise the accuracy of this approach (e.g., Oppenheimer et al., 2014). As discussed in Section "Gas-Water Interaction of Magmatic Fluids," the trend of the variation of Kolumbo gases is modulated by the process of $\mathrm{CO}_{2}$ dissolution in water, which can be observed in Figure 8. However, the backcorrected calculated values for the gas composition produced $\delta^{13} \mathrm{C}_{\mathrm{CO}_{2}}$ and $\mathrm{CO}_{2} /{ }^{3} \mathrm{He}$ values of $-0.4 \%$ and $1.28 \times 10^{10}$, respectively. This $\mathrm{CO}_{2} /{ }^{3} \mathrm{He}$ ratio falls within the range of values reported for gases emitted from arc volcanoes worldwide $\left(\geq 10^{10}\right.$; Hilton et al., 2002), while $\delta^{13} \mathrm{C}_{\mathrm{CO}_{2}}$ is within the range proposed for limestone $\left(\mathrm{CO}_{2} /{ }^{3} \mathrm{He} \sim 1 \times 10^{13}, \delta^{13} \mathrm{C}=-1\right.$ to $+1 \%$; Sano and Marty, 1995). Figure 8 presents the binary mixing line between MORB $\left(\mathrm{CO}_{2} /{ }^{3} \mathrm{He}=2 \times 10^{9}, \delta^{13} \mathrm{C}=-4 \% 0\right)$ and limestone (assuming $\mathrm{CO}_{2} /{ }^{3} \mathrm{He}=1 \times 10^{13}, \delta^{13} \mathrm{C}=0 \%$ ), which highlights that gases emitted at Kolumbo have a MORB source contaminated by limestone. The main question arising from this evaluation is whether the contamination by carbonates occurs in the mantle (by subduction of limestone-bearing sediments) or in the crust (from carbonates in the basement). Unfortunately we have not performed any direct measurements of mantle fluids that could shed light on this question for Kolumbo, in contrast to the values measured for the mantle cumulates at Stromboli arc volcano (Gennaro et al., 2017). We therefore attempted to address this issue indirectly by comparing our data with those for fumarole gases emitted at Santorini (Nea Kameni Island) and Nisyros (Figure 8), which are the most-active volcanoes along HVA. Recent measurements of fumarole samples from Santorini (Rizzo et al., 2015) produced $\delta^{13} \mathrm{C}_{\mathrm{CO}_{2}}$ and $\mathrm{CO}_{2} /{ }^{3} \mathrm{He}$ values that are comparable to those for Kolumbo gases, despite the considerable variability that may have been caused by gaswater interaction, similarly to our case study (Figure 8). In detail, ${ }^{13} \mathrm{C}_{\mathrm{CO}_{2}}$ as measured previously at Nea Kameni fumaroles was $-0.2 \pm 2.7 \%$ (Dotsika et al., 2009; Parks et al., 2013; Tassi et al., 2013), which is consistent with the present results for Kolumbo (Figure 8). Similar $\delta^{13} \mathrm{C}_{\mathrm{CO}_{2}}$ and $\mathrm{CO}_{2} /{ }^{3} \mathrm{He}$ values were also found by Brombach et al. (2003) for Nisyros fumaroles, although those data exhibited substantial variability. However, the reported range of values fell mainly within the binary mixing line between MORB and limestone, as observed for Santorini and Kolumbo gases.

Parks et al. (2013) proposed that the C-isotope signature of $\mathrm{CO}_{2}$ emitted at Santorini and Nisyros is consistent with mixing between magmatic fluids and crustal basement limestone, the presence of which has been inferred by Nicholls (1971) and Spandler et al. (2012). This interpretation is plausible for two main reasons: (1) similar $\delta^{13} \mathrm{C}_{\mathrm{CO}_{2}}$ signatures characterize most of the Mediterranean volcanoes where there is evidence of the presence of a carbonate basement, and (2) the $\delta^{13} \mathrm{C}_{\mathrm{CO}_{2}}$ variability 


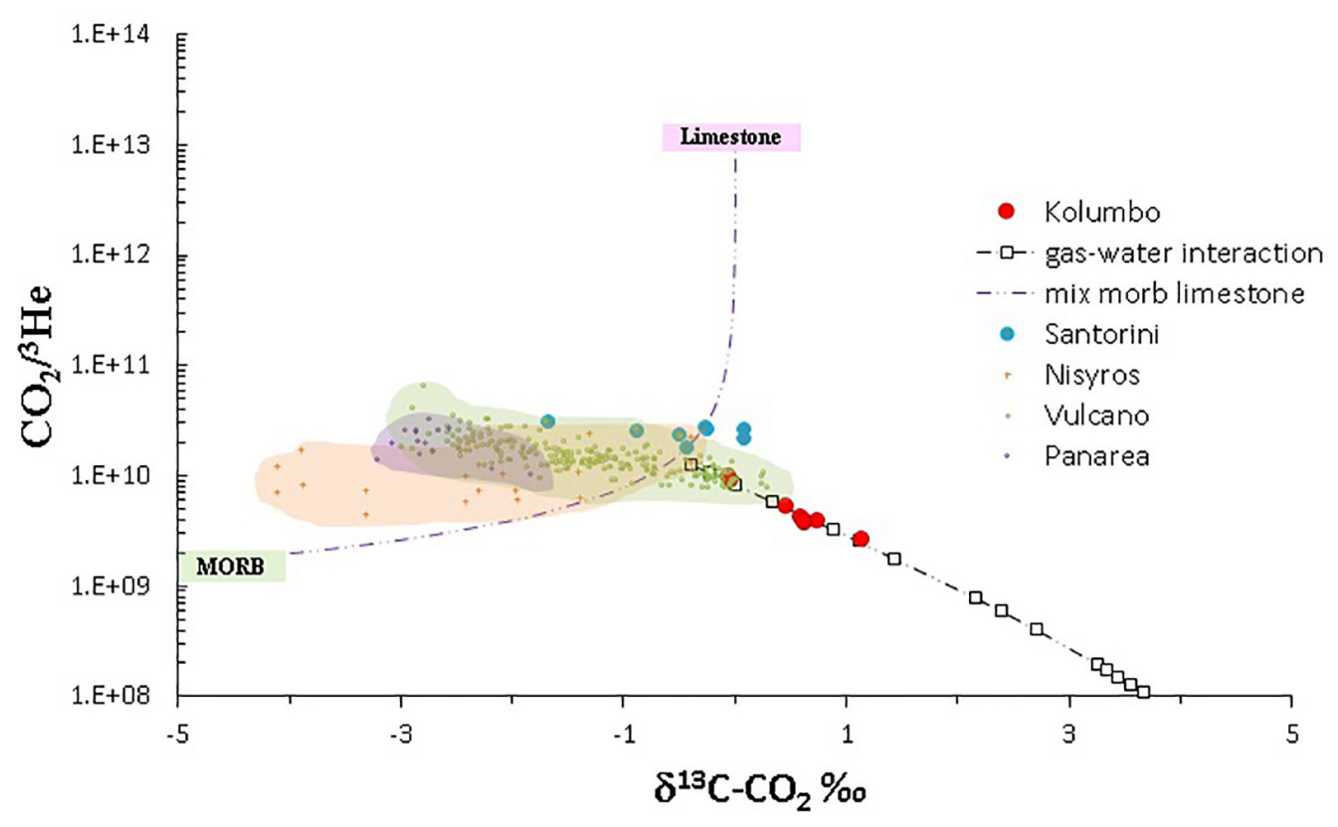

FIGURE 8| Plot of $\delta^{13} \mathrm{C}_{\mathrm{CO}_{2}}$ versus $\mathrm{CO}_{2} /{ }^{3} \mathrm{He} .{ }^{3} \mathrm{He}$ data are taken from Rizzo et al. (2016), who analyzed the same suite of gas samples. Data for Santorini, Nisyros, Vulcano, and Panarea are from Brombach et al. (2003), Paonita et al. (2013), Tassi et al. (2014), and Rizzo et al. (2015), respectively. The violet dotted curve represents binary mixing between a MORB-like upper mantle having $\delta^{13} \mathrm{C}=-4 \%$ and $\mathrm{CO}_{2} /{ }^{3} \mathrm{He}=2 \times 10^{9}$, and limestone having $\delta^{13} \mathrm{C}=0 \%$ and $\mathrm{CO}_{2} /{ }^{3} \mathrm{He}=1 \times 10^{13}$ (Marty and Jambon, 1987; Javoy and Pineau, 1991; Sano and Marty, 1995). The black dotted line represents the path of selective dissolution of gases in water modeled by an open-system condensation process under equilibrium conditions. The starting gas composition for modeling was $\delta^{13} \mathrm{C}_{\mathrm{CO}_{2}}=-0.4 \%$ and $\mathrm{CO}_{2} /{ }^{3} \mathrm{He}=1.26 \times 10^{10}$. The symbols are as in Figure 5.

observed in fumaroles at Santorini during the 2011-2012 unrest (Tassi et al., 2013) is not compatible with a mantle signature modified by subducted carbonates (Parks et al., 2013). In further support of the hypothesis of Parks et al. (2013), we highlight that there is strong evidence for the presence of Mesozoic carbonates within the crust beneath Kolumbo (Kilias et al., 2013). However, Rizzo et al. (2016) reported that the ${ }^{3} \mathrm{He} /{ }^{4} \mathrm{He}$ signature of Kolumbo gases is indicative of the direct degassing of a MORBlike mantle, while those at Santorini are subsequently modified by crustal contamination. Those authors therefore argued that the mantle beneath Kolumbo and Santorini is homogeneous in terms of the He-isotope signature.

We consider that the consistency of the $\delta^{13} \mathrm{C}_{\mathrm{CO}_{2}}$ signatures at Santorini, Kolumbo, Nisyros, and most Mediterranean volcanoes with MORB and limestone mixing represents evidence of mantle metasomatism induced by decarbonation of subducting limestone-bearing sediments, rather than mixing of comparable proportions of magmatic and crustal fluids originating from local basement carbonates. Indeed, based on $\delta^{13} \mathrm{C}_{\mathrm{CO}_{2}}$ in fluid inclusions of mantle cumulates from Stromboli, Gennaro et al. (2017) revealed that the isotopic signature of local mantle reflected $\mathrm{CO}_{2}$ contamination arising from the decarbonation of sediments carried by the subducting Ionian slab. We therefore argue that the mantle beneath Kolumbo and Santorini is reasonably homogeneous also in terms of $\delta^{13} \mathrm{C}_{\mathrm{CO}_{2}}$ signatures, and we cannot exclude that $\mathrm{CO}_{2}$ is already contaminated by the decarbonation of slab sediments. Local crustal contamination may eventually further modify the isotopic composition of metasomatized mantle $\mathrm{C}$, as observed for He isotopes beneath Santorini (Rizzo et al., 2015, 2016).

\section{Origin of $\mathrm{CH}_{4}$}

Some studies have focused on the origin of $\mathrm{CH}_{4}$ in fluids emitted from submarine hydrothermal systems (Welhan, 1988; McCollom and Seewald, 2007; Proskurowski et al., 2008; Keir, 2010; McDermott et al., 2015; Wen et al., 2016; Xue-Gang et al., 2016; Wang et al., 2018; and references therein). Besides the difficulty of sampling at considerable water depths, the availability of $\mathrm{CH}_{4}$ data is further impaired by the gases emitted from hydrothermal or magmatic systems generally being dominated by $\mathrm{CO}_{2}$ (e.g., Yang et al., 2005; Lupton et al., 2006, 2008), with only trace levels of $\mathrm{CH}_{4}$. This compromises the ability to perform isotope analyses, especially those of $\mathrm{H}$.

In this study we measured the stable $\mathrm{C}$ and $\mathrm{H}$ isotopes of $\mathrm{CH}_{4}$ in Kolumbo hydrothermal gases and performed evaluations to ascertain the origin of $\mathrm{CH}_{4}$. In this context we plotted ${ }^{13} \mathrm{C}_{\mathrm{CH}_{4}}$ versus $\mathrm{CH}_{4} /\left(\mathrm{C}_{2} \mathrm{H}_{6}+\mathrm{C}_{3} \mathrm{H}_{8}\right)$, which is the most-common classification approach that was introduced by Bernard et al. (1978), and $\delta \mathrm{D}_{\mathrm{CH}_{4}}$ versus $\delta^{13} \mathrm{C}_{\mathrm{CH}_{4}}$, as introduced by Schoell (1980) and later modified by Mazzini et al. (2011), to distinguish $\mathrm{CH}_{4}$ originating from thermogenic and microbial processes as well as sediment-free midocean ridges (Figure 9). It should be stressed that the $\mathrm{CH}_{4}$-isotope composition of Kolumbo gases (Table 1) varied within a narrow range for both $\mathrm{C}$ $\left(\delta^{13} \mathrm{C}=-18.8\right.$ to $\left.-17.6 \% \mathrm{~V}-\mathrm{PDB}\right)$ and $\mathrm{H}(\delta \mathrm{D}=-118.6$ to $-115.4 \% \mathrm{~V}-\mathrm{SMOW})$. The data points in the plot of $\delta^{13} \mathrm{C}_{\mathrm{CH}_{4}}$ 

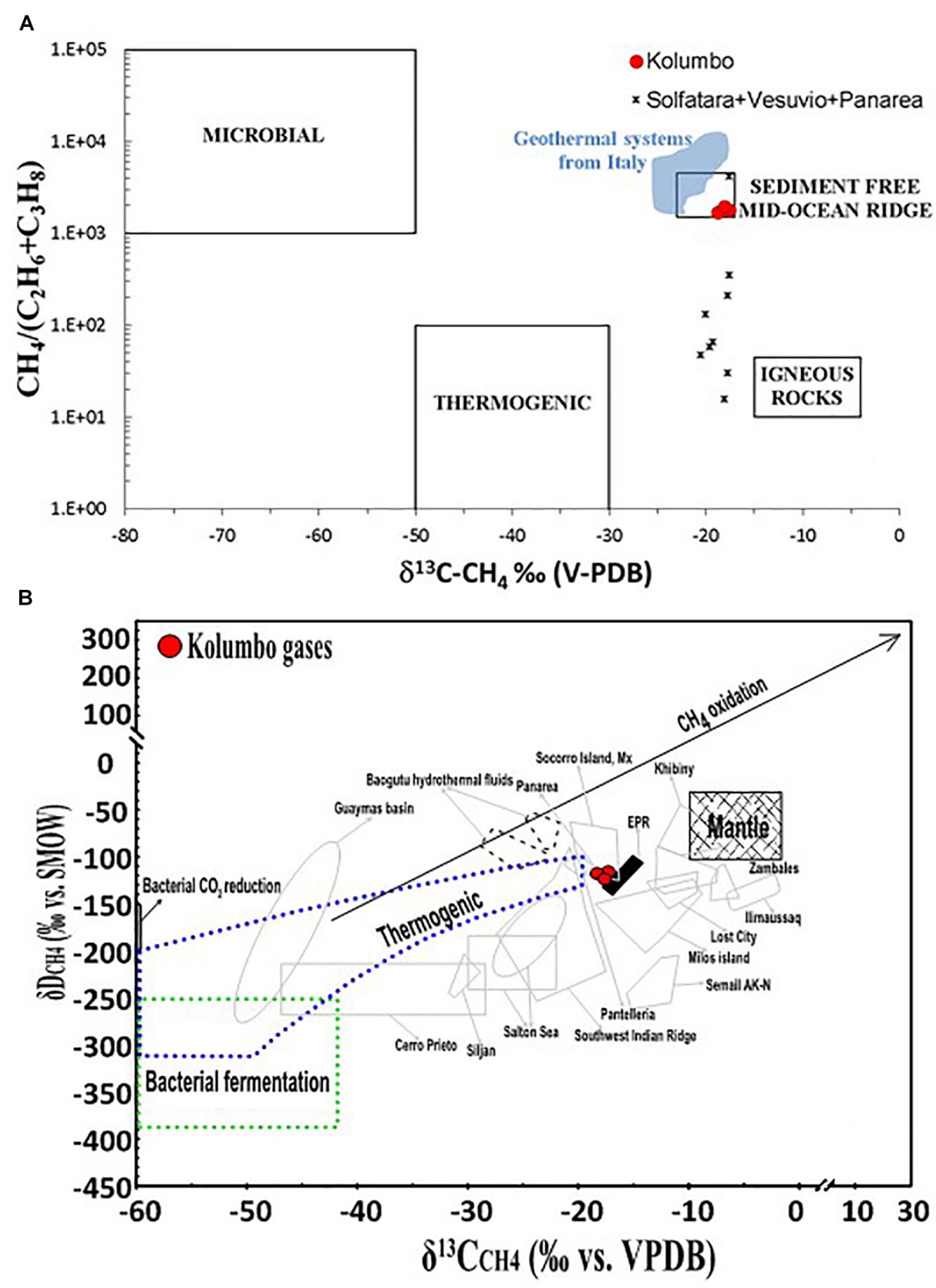

FIGURE 9 | (A) Plot of $\delta^{13} \mathrm{C}_{\mathrm{CH}_{4}}$ versus $\mathrm{CH}_{4} /\left(\mathrm{C}_{2} \mathrm{H}_{6}+\mathrm{C}_{3} \mathrm{H}_{8}\right)$ modified from Bernard et al. (1978). Field data for microbial and thermogenic gases and from sediment-free midocean ridges and for igneous rocks are from McCollom and Seewald (2007 and references therein). Data for Italian geothermal systems and hydrothermal systems from Campi Flegrei, Vesuvio and Panarea are from Tassi et al. (2012 and references therein). (B) Plot of $\delta \mathrm{D}_{\mathrm{CH}_{4}}{ }$ versus $\delta^{13} \mathrm{C}_{\mathrm{CH}}{ }_{4}$ as introduced by Schoell (1980) and modified by Mazzini et al. (2011). Field data are from Mazzini et al. (2011 and references therein). The symbols are as in Figure 5.

versus $\mathrm{CH}_{4} /\left(\mathrm{C}_{2} \mathrm{H}_{6}+\mathrm{C}_{3} \mathrm{H}_{8}\right)$ for Kolumbo samples (Figure 9A) fall within an origin area of the sediment-free midocean ridge, similar to other Italian geothermal and hydrothermal systems (e.g., Panarea and Pantelleria; Tassi et al., 2012). Such data are often classified as abiogenic (McCollom and Seewald, 2007 and references therein), meaning that methanogenesis does not involve a biogenic organic precursor (Welhan, 1988). Nevertheless, the accuracy of this approach can be significantly compromised since the concentrations of light hydrocarbons and the isotopic composition of $\mathrm{CH}_{4}$ can both be modified by oxidation and migration processes (Welhan, 1988). More specifically, $\delta \mathrm{D}_{\mathrm{CH}_{4}}$ and $\delta^{13} \mathrm{C}_{\mathrm{CH}_{4}}$ measured in Kolumbo gases may have been altered by thermogenic gas oxidation, as in the case of $\mathrm{CH}_{4}$ from Salton Sea Geothermal Field (Mazzini et al., 2011). Alternatively, it is possible that abiogenic $\mathrm{CH}_{4}$ is either formed in basalts and extracted into the circulating 
fluids (Welhan, 1988) or produced by Fischer-Tropsch-type chemical reactions (e.g., Proskurowski et al., 2008; Keir, 2010 and references therein; Etiope and Sherwood-Lollar, 2013). However, the latter process was recently questioned by Taran et al. (2010a), who attributed the isotopic trends in the $\delta^{13} \mathrm{C}$ and $\delta \mathrm{D}$ values of light hydrocarbons as mixing between two or more endmembers.

On the other hand, the plot of $\delta \mathrm{D}_{\mathrm{CH}_{4}}$ versus $\delta^{13} \mathrm{C}_{\mathrm{CH}_{4}}$ for Kolumbo samples (Figure 9B) falls within the area of Socorro gases (Mexico, Taran et al., 2010b), between the range of abiotic $\mathrm{CH}_{4}$ (McCollom and Seewald, 2007 and references therein) and a thermogenic field, which is how most geothermal and hydrothermal systems worldwide are generally characterized (Whiticar, 1999; Mango, 2000; Taran et al., 2010b; Tassi et al., 2012). By combining He-isotope data (i.e., ${ }^{3} \mathrm{He} /{ }^{4} \mathrm{He}$ ratio of $\sim 7$ Ra for Kolumbo gases; Rizzo et al., 2016) with those of $\mathrm{CH}_{4}$ (e.g., Hsin-Yi et al., 2016), we obtained an average $\mathrm{CH}_{4} /{ }^{3} \mathrm{He}$ ratio of $\sim 1.4 \times 10^{7}$ (Table 1). This ratio falls within the range of values measured in fluids from the East Pacific Rise (e.g., Proskurowski et al., 2008; Keir, 2010; and references therein).

Christakis et al. (2018) analyzed the microbial community at Kolumbo sulfide chimneys using next-generation sequencing technologies, and did not find any microbial lineages closely related to $\mathrm{CH}_{4}$ production processes. In addition, only a few phylotypes typically involved in $\mathrm{CH}_{4}$ oxidation were identified. A further metagenomic investigation of the Kolumbo seafloor found negligible methanogenesis-related marker genes (Oulas et al., 2015), supporting the abiotic origin of $\mathrm{CH}_{4}$.

It was beyond the scope of this study to resolve the scientific controversies of the different theories about abiotic $\mathrm{CH}_{4}$. Overall, it is more likely that $\mathrm{CH}_{4}$ in Kolumbo gases comprise a mixture of oxidized thermogenic and abiogenic $\mathrm{CH}_{4}$ formed in hightemperature $\left(>200^{\circ} \mathrm{C}\right)$ magmatic-hydrothermal systems.

\section{Submarine Hydrothermal $\mathrm{Hg}(0)$ Emissions}

The natural aerial volcanic emissions of $\mathrm{Hg}$ via passive degassing have been estimated at $76 \pm 30 \times 10^{6} \mathrm{~g} \mathrm{yr}^{-1}$ (Bagnato et al., 2014). However, the quantity and impact of Hg released by submarine volcanoes and hydrothermal systems is less well-known due to a lack of observations (Varekamp and Buseck, 1981; Bagnato et al., 2017). In particular, there are severe logistical constraints in sampling submarine volcanic gas emissions on the floor of Kolumbo submarine crater, since it is at $500 \mathrm{~m}$ b.s.l. (Fitzgerald and Lamborg, 2004). Moreover, previous studies of submarine hydrothermal $\mathrm{Hg}$ have investigated dissolved $\mathrm{Hg}(\mathrm{II})$ concentrations but not dissolved gaseous $\mathrm{Hg}(0)$ (Lamborg et al., 2006).

The present study deployed gas-tight titanium syringes connected to inverted funnels above hydrothermal vents and activated by an ROV, which provided the unique opportunity to collect pristine bubbling gas emissions discharged from an active submarine volcano. The levels of gaseous $\operatorname{Hg}(0)$ in the gas samples varied from 61 to $1300 \mathrm{ng} \mathrm{m}^{-3}$, which are roughly 10 times higher than the levels previously reported for on-land Santorini fumaroles (9 to $121 \mathrm{ng} \mathrm{m}^{-3}$; Bagnato et al., 2013) and also the worldwide aerial volcanic $\operatorname{Hg}(0)$ concentrations (4 to $125 \mathrm{ng} \mathrm{m}^{-3}$; Bagnato et al., 2014). These data seem to further highlight that the level of magmatic activity is higher at
Kolumbo volcano than at Santorini. It is also worth mentioning that the global average concentration of atmospheric $\mathrm{Hg}(0)$ in the northern hemisphere is $1.5 \mathrm{ng} \mathrm{m}^{-3}$.

\section{Hydrothermal Gas Equilibrium}

The temperature and pressure conditions at which gaseous species equilibrate in the hydrothermal system beneath the floor of Kolumbo submarine crater can be estimated from concentration data of minor reactive species together with $\mathrm{CO}_{2}$ and $\mathrm{H}_{2} \mathrm{O}$ (Chiodini and Marini, 1998 and references therein). The most-important assumptions in this approach are that the gaseous species have attained chemical equilibrium in the hydrothermal system and are quenched during their ascent to the sea surface. We evaluated two stability diagrams based on the concentrations of $\mathrm{H}_{2}, \mathrm{CO}, \mathrm{CH}_{4}$, and $\mathrm{CO}_{2}$ in the dry gas phase (Figure 10), following the approach proposed by Chiodini and Cioni (1989) and Chiodini et al. (2001) and subsequently modified by Chiodini et al. (2006) for submarine gases at Panarea. Because $\mathrm{H}_{2} \mathrm{O}$ represents the main component of hydrothermal fluids, we assumed that pure water coexisted with vapor, whereas the fugacity of water vapor $\left(f \mathrm{H}_{2} \mathrm{O}\right)$ as a function of temperature (Giggenbach, 1987) can be expressed as follows:

$$
\log \left(f \mathrm{H}_{2} \mathrm{O}\right)(\text { bar })=5.510-2048 / T
$$

where $T$ is the temperature in kelvin. It is also important to consider the fugacity of $\mathrm{O}_{2}\left(f \mathrm{O}_{2}\right)$, since this controls the redox conditions at which hydrothermal systems are formed. Since the $\mathrm{H}_{2} \mathrm{O}$ concentration of hydrothermal vapors in our samples was not available and we have no information on the mineral assemblage that could fix $f \mathrm{O}_{2}$, we considered the redox buffer typically proposed for hydrothermal systems by D'Amore and Panichi (1980):

$$
\log \left(f \mathrm{O}_{2}\right)(\text { bar })=8.20-23643 / T
$$

Complementarily, we considered the following reactions and temperature-dependent equilibrium constants based on the thermodynamic data reported by Stull et al. (1969) and Giggenbach (1980, 1987):

$$
\begin{array}{ll}
\mathrm{H}_{2} \mathrm{O} \leftrightarrow \mathrm{H}_{2}+\frac{1}{2} \mathrm{O}_{2} & \log \left(K_{\mathrm{H}_{2} \mathrm{O}}\right)=2.548-12707 / T \\
\mathrm{CO}_{2} \leftrightarrow \mathrm{CO}+\frac{1}{2} \mathrm{O}_{2} & \log \left(K_{\mathrm{CO}_{2}}\right)=5.033-14955 / \mathrm{T} \\
\mathrm{CO}_{2}+2 \mathrm{H}_{2} \leftrightarrow \mathrm{CH}_{4}+\mathrm{O}_{2} & \log \left(K_{\mathrm{CO}_{2}+\mathrm{H}_{2}}\right)=-4.569-16593 / T
\end{array}
$$

Finally, the following equations derived by Chiodini et al. (2006) were taken into account:

$$
\begin{gathered}
\log \left(\mathrm{H}_{2} / \mathrm{CH}_{4}\right)=8.811-4121.5 / T-\log \left(P_{\mathrm{CO}_{2}}\right) \\
\log \left(\mathrm{CO} / \mathrm{CH}_{4}\right)=5.786-4326.5 / T
\end{gathered}
$$

where $P$ is the partial pressure. The plot of $\log \left(\mathrm{CO} / \mathrm{CH}_{4}\right)$ versus $\log \left(\mathrm{H}_{2} / \mathrm{CH}_{4}\right)$ in Figure 10A suggests that Kolumbo gases would have reached an equilibrium at $200-250^{\circ} \mathrm{C}$ and $P_{\mathrm{CO}_{2}} \sim 50$ bar. In comparison with the submarine hydrothermal system of Panarea and the high-temperature fumaroles of Vulcano (Aeolian Islands, 

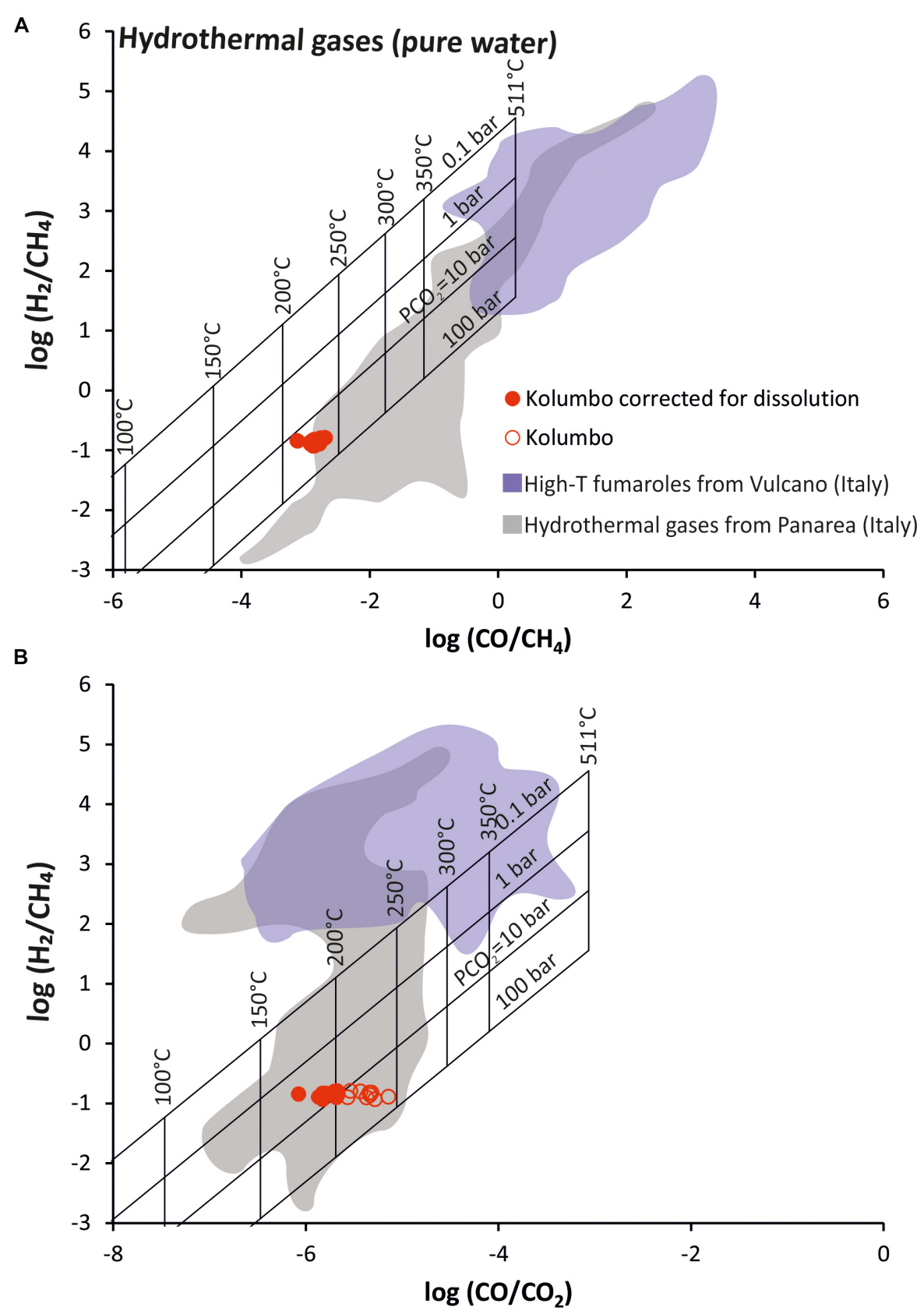

FIGURE 10 | Plots of (A) $\log \left(\mathrm{CO} / \mathrm{CH}_{4}\right)$ versus $\log \left(\mathrm{H}_{2} / \mathrm{CH}_{4}\right)$ and $\mathbf{( B )} \log \left(\mathrm{CO} / \mathrm{CO}_{2}\right)$ versus $\log \left(\mathrm{H}_{2} / \mathrm{CH}_{4}\right)$. The theoretical grid for hydrothermal gases was calculated by assuming their coexistence with pure liquid water (Chiodini et al., 2006 and references therein). Data for Vulcano Island are from Paonita et al. (2013), and those for Panarea are from Caracausi et al. (2005), Chiodini et al. (2006), and Tassi et al. (2014). The symbols are as in Figure 5. See the main text for further details.

Italy), Kolumbo gases fall close to or within the range for Panarea gases, confirming their hydrothermal nature. The same pressure and temperature conditions were derived by examining the plot of $\log \left(\mathrm{CO} / \mathrm{CO}_{2}\right)$ versus $\log \left(\mathrm{H}_{2} / \mathrm{CH}_{4}\right)$ (Figure 10B). Given the compositional changes that may arise in hydrothermal gases due to the partial dissolution of $\mathrm{CO}_{2}$ in water (see section "Gas-Water Interaction of Magmatic Fluids"), we recalculated the pressure and temperature conditions by applying the pristine composition estimated for each gas vent. Based on the values of Henry's law constant, $\mathrm{CO}_{2}$ was found to differ considerably from $\mathrm{H}_{2}$, $\mathrm{CO}$ and $\mathrm{CH}_{4}$, with the former having a greater tendency to partition from the gas phase into the aqueous phase (Sander, 2015). Therefore, the correction for gas-water partitioning was deemed necessary only when considering ratios that involved $\mathrm{CO}_{2}$ [e.g., $\log \left(\mathrm{CO} / \mathrm{CO}_{2}\right)$; Figure 10B]. By applying the pristine composition, we estimated a gas equilibrium temperature of 
$\sim 200^{\circ} \mathrm{C}$ and $P_{\mathrm{CO}_{2}} \sim 10$ bar. These values are slightly lower than the pressure and temperature conditions derived from the plot of $\log \left(\mathrm{CO} / \mathrm{CH}_{4}\right)$ versus $\log \left(\mathrm{H}_{2} / \mathrm{CH}_{4}\right)$, but they remain well within the typical values reported for hydrothermal gases. In general, the estimated temperature using $\mathrm{CO} / \mathrm{CH}_{4}, \mathrm{CO} / \mathrm{CO}_{2}$, and $\mathrm{H}_{2} / \mathrm{CH}_{4}$ was equal to or below the highest temperature measured on the floor of Kolumbo submarine crater vents by Sigurdsson et al. (2006) and Carey et al. (2013). This suggests that part or all of these gaseous species did not achieve equilibrium under the assumed redox conditions or that the magmatic activity has waned in recent years.

To investigate these two possibilities, we applied the approach proposed by Chiodini and Cioni (1989) and Chiodini et al. (2006), which is based on the reaction:

$$
\mathrm{CH}_{4}+3 \mathrm{CO}_{2} \leftrightarrow 4 \mathrm{CO}+2 \mathrm{H}_{2} \mathrm{O}
$$

Since this reaction does not involve gaseous $\mathrm{O}_{2}$, Chiodini et al. (2006) suggested that this approach provides equilibrium pressure and temperature estimates that are independent of the redox conditions. The resulting equations that allow pressure and temperature to be determined are

$$
\begin{gathered}
T(K)\left[\frac{13606}{8065-\log \left(\frac{\mathrm{CO}^{4}}{\mathrm{CO}_{2}^{3} \cdot \mathrm{CH}_{4}}\right)}\right] \\
\log \mathrm{P}_{\mathrm{CO}_{2}} \text { (bar) }=3.573-\frac{46}{\mathrm{~T}(\mathrm{~K})}-\log \left(\frac{\mathrm{H}_{2}}{\mathrm{CO}}\right)
\end{gathered}
$$

This specific approach revealed that Kolumbo gases equilibrated at $200-250^{\circ} \mathrm{C}$ and when $\mathrm{P}_{\mathrm{CO}_{2}}$ was slightly below 50 bar (Figure 11A). The presence of $\mathrm{CO}_{2}$ in one of the above equations prompted us to again consider the pristine composition of gases prior to the gas-water partitioning process. This yielded a slightly lower equilibrium temperature $\left(189-216^{\circ} \mathrm{C}\right)$, whereas $\mathrm{P}_{\mathrm{CO}_{2}}$ remained the same (Figure 11A). This temperature range is comparable to those estimated using $\mathrm{CO} / \mathrm{CH}_{4}, \mathrm{CO} / \mathrm{CO}_{2}$ and $\mathrm{H}_{2} / \mathrm{CH}_{4}$ ratios, suggesting that the assumed redox conditions are not responsible for the difference in the estimated equilibrium temperatures.

The findings of previous investigations of crater fumaroles at White Island (Giggenbach, 1987) and Vulcano (Chiodini et al., 1993, 1995) suggest that the two most-reactive gaseous species in hydrothermal systems are $\mathrm{H}_{2}$ and $\mathrm{CO}$, while $\mathrm{CH}_{4}$ is one of the least reactive (Giggenbach, 1991; Taran and Giggenbach, 2003). To evaluate if $\mathrm{CH}_{4}$ measured in Kolumbo gases attained full equilibrium, we considered the following formation reaction and relative equilibrium constant:

$$
\begin{gathered}
\mathrm{CO}_{2}+\mathrm{H}_{2} \leftrightarrow \mathrm{CO}+\mathrm{H}_{2} \mathrm{O} \\
\log \left(\mathrm{K}_{\mathrm{CO}_{2}+\mathrm{H}_{2}}\right)=\log \left(\mathrm{CO} / \mathrm{CO}_{2}\right)-\log \left(\mathrm{H}_{2} / \mathrm{H}_{2} \mathrm{O}\right)
\end{gathered}
$$

In the gas phase, $\log \left(\mathrm{K}_{\mathrm{CO}_{2}+\mathrm{H}_{2}}\right)=-2248 / \mathrm{T}+2.485$

In a single saturated liquid phase, as assumed in our case, gas equilibrium contents are computed using the vapor-liquid

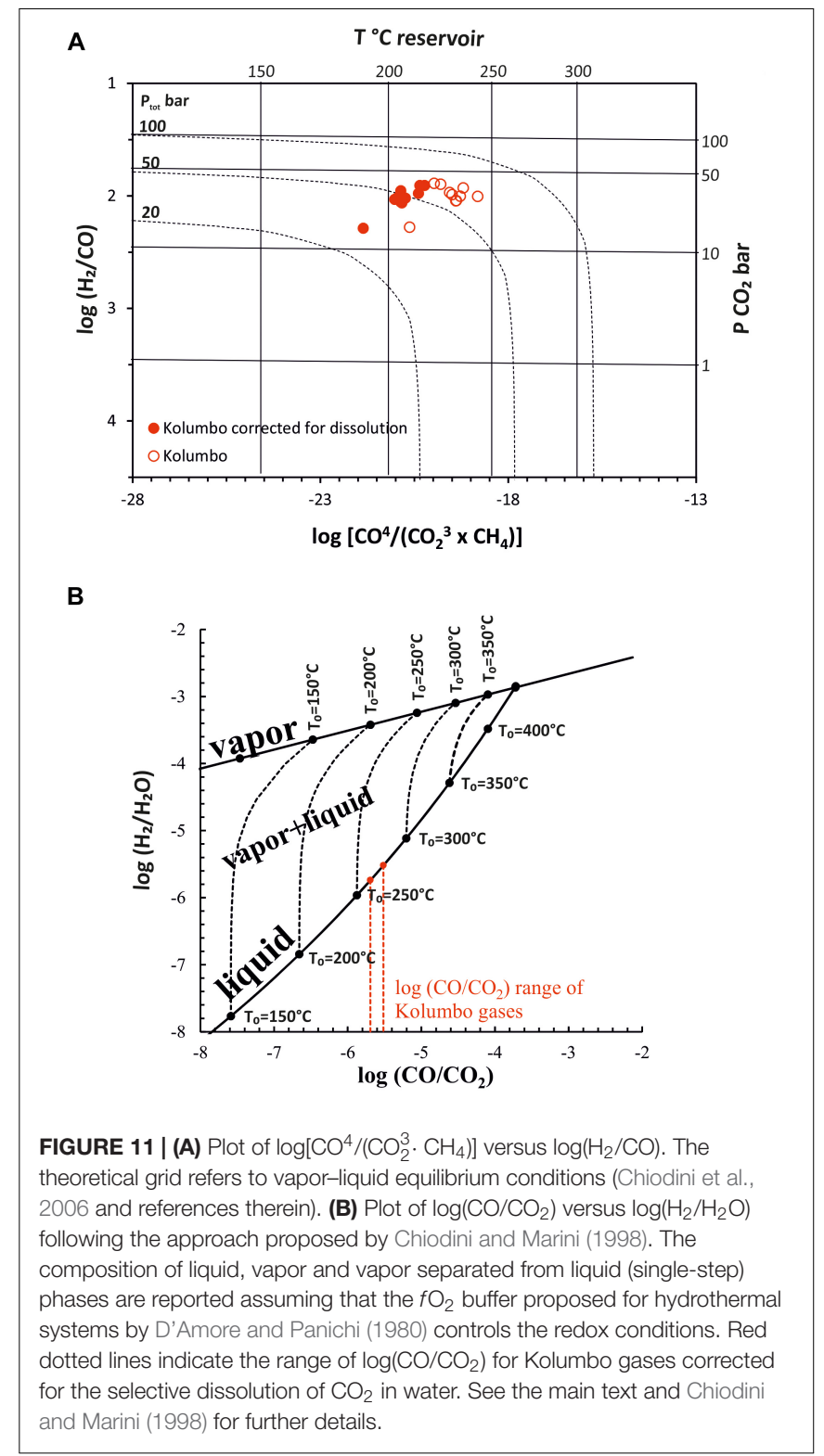

distribution coefficient (B) (Giggenbach, 1980; D’Amore and Truesdell, 1988; Chiodini and Marini, 1998):

$$
\begin{gathered}
\log \left(\mathrm{B}_{\mathrm{CO}}\right)=6.3173-0.01388(\mathrm{~T}-273.15) \\
\log \left(\mathrm{B}_{\mathrm{CO}_{2}}\right)=4.7593-0.01092(\mathrm{~T}-273.15) \\
\log \left(\mathrm{B}_{\mathrm{H}_{2}}\right)=6.2283-0.01403(\mathrm{~T}-273.15)
\end{gathered}
$$

Therefore, the above reported reaction for the liquid phase becomes

$$
\begin{aligned}
& \log \left(\mathrm{K}_{\mathrm{CO}_{2}+\mathrm{H}_{2}}\right)-\log \left(\mathrm{B}_{\mathrm{CO}} / \mathrm{B}_{\mathrm{CO}_{2}}\right)+\log \left(\mathrm{B}_{\mathrm{H}_{2}}\right) \\
& =\log \left(\mathrm{CO} / \mathrm{CO}_{2}\right)-\log \left(\mathrm{H}_{2} / \mathrm{H}_{2} \mathrm{O}\right)
\end{aligned}
$$

An equilibrium temperature of $250-300^{\circ} \mathrm{C}$ and $\log \left(\mathrm{K}_{\left.\mathrm{CO}_{2}+\mathrm{H}_{2}\right)}\right)$ $-\log \left(\mathrm{B}_{\mathrm{CO}} / \mathrm{B}_{\mathrm{CO}_{2}}\right)+\log \left(\mathrm{B}_{\mathrm{H}_{2}}\right) \approx 0.0 \pm 0.1$ implies $\log \left(\mathrm{H}_{2} / \mathrm{H}_{2} \mathrm{O}\right)$ $\approx \log \left(\mathrm{CO} / \mathrm{CO}_{2}\right)$. Thus, the $\log \left(\mathrm{CO} / \mathrm{CO}_{2}\right)$ values measured in our 


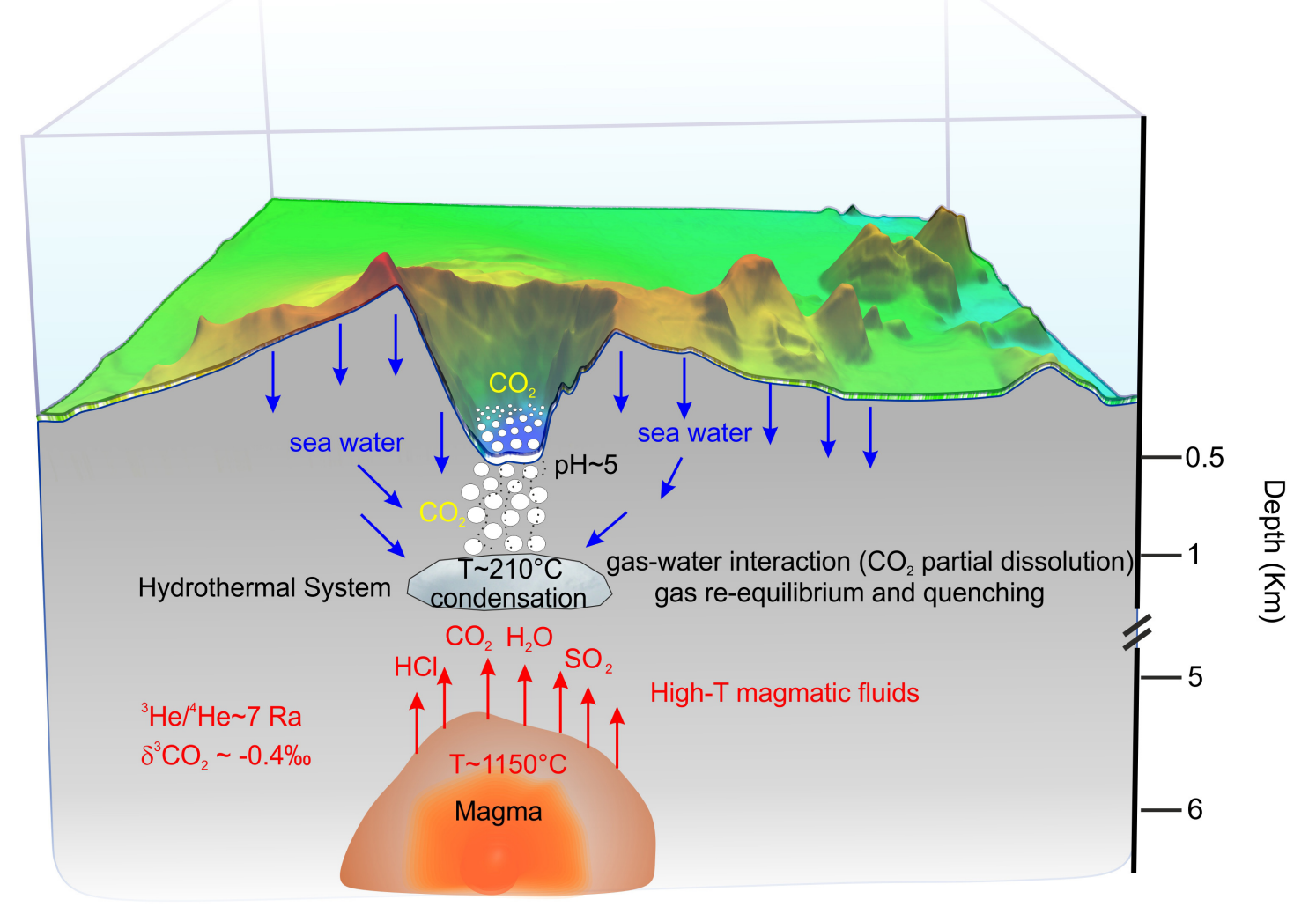

FIGURE 12 | Conceptual scheme of the hydrothermal system beneath Kolumbo. The location of the shallow magma chamber at 5-7 km beneath Kolumbo is from Dimitriadis et al. (2010), Konstantinou and Yeh (2012), and Cantner et al. (2014). The He-isotope composition is from Rizzo et al. (2016).

samples and corrected for $\mathrm{CO}_{2}$ dissolution can be used to roughly estimate the equilibrium temperature in liquid water, which varies in the narrow range of $263-276^{\circ} \mathrm{C}$ (Figure 11B). These values are higher than those previously calculated including $\mathrm{CH}_{4}$, and thus we deduce that the latter species was not in equilibrium with the other gases and led to underestimations of the equilibrium temperature.

Based on the relationships proposed by Chiodini and Cioni (1989), we can finally calculate $P_{\mathrm{CO}_{2}} \sim 30$ bar and $P_{\mathrm{H}_{2} \mathrm{O}} \sim 36$ bar, which sum to a total pressure of $\sim 66$ bar. Considering that Kolumbo gases are emitted at $500 \mathrm{~m}$ b.s.l., which corresponds to a pressure of $\sim 50$ bar, the hydrothermal system must be located at a pressure of $\sim 116$ bar $(\sim 1000 \mathrm{~m}$ b.s.l. $)$.

\section{Conceptual Scheme of the Hydrothermal System Beneath Kolumbo}

Based on this study and other previous findings (Sigurdsson et al., 2006; Carey et al., 2013; Kilias et al., 2013; Rizzo et al., 2016), in Figure 12 we propose a physical and geochemical model for the Kolumbo magmatic-hydrothermal system. We made some assumptions in order to simplify the system: (1) the permeability of the system was considered uniform, isotropic and sufficiently high; (2) the shallow magma chamber located 5-7 $\mathrm{km}$ beneath Kolumbo (Dimitriadis et al., 2010; Konstantinou and Yeh, 2012; Cantner et al.,
2014) represents the source of magmatic gases feeding the hydrothermal system, (3) magmatic degassing does not or only weakly modifies these magmatic gases, and (4) seawater infiltrates from the sea bottom and favors condensation of magmatic gases both within and above the hydrothermal system.

At Kolumbo, magmatic gases $\left(\mathrm{H}_{2} \mathrm{O}, \mathrm{CO}_{2}\right.$, S-bearing species, halogens and noble gases) having ${ }^{3} \mathrm{He} /{ }^{4} \mathrm{He} \sim 7 \mathrm{Ra}$ (Rizzo et al., 2016) and $\delta^{13} \mathrm{C}_{\mathrm{CO}_{2}} \sim-0.4 \%$ ascend from the magma chamber and feed conduits up to the hydrothermal system (Figure 12). During the cooling of magmatic gases, $\mathrm{H}_{2} \mathrm{O}$ and more-acidic species ( $\mathrm{S}$ and halogens) condensate to form a hydrothermal system at $\sim 270^{\circ} \mathrm{C}$ in which water at $\mathrm{pH} \leq 5$ probably circulates. We cannot exclude that the hydrothermal system has multiple levels; however, we are able to reconstruct the upper level that feeds the bottom vents of the crater. Hydrothermal waters are probably fed by seawater infiltrating from the sea bottom and any brine formed from the adsorption of acidic gases in groundwater by rock dissolution.

The hydrothermal system has a total pressure of $\sim 66$ bar, corresponding to $\sim 1,160 \mathrm{~m} \mathrm{b.s.l}$. and $650 \mathrm{~m}$ below the crater bottom, if the hydrostatic pressure is assumed at depth. Hydrothermal gases within the hydrothermal system undergo gas-water interactions along the fractures feeding the floor of 
Kolumbo submarine crater and from the shallow vents that favor the removal of most of the acidic gases ( $\mathrm{S}$ and halogens) and the partial dissolution of $\mathrm{CO}_{2}$ (see section "Gas-Water Interaction of Magmatic Fluids"). This produces an excess of $\mathrm{N}_{2}$, noble gases and reactive gases via migration paths that permit their rapid ascent under advective degassing. At the crater bottom, several vents discharge fluids at temperatures up to $220^{\circ} \mathrm{C}$, variable gas fluxes and $\mathrm{pH}$ down to $\sim 5$ (Sigurdsson et al., 2006; Carey et al., 2013). Acoustic and visual imaging of the ascending bubbles suggests that $\mathrm{CO}_{2}$ is being dissolved into seawater within $\sim 10 \mathrm{~m}$ above the crater floor (Carey et al., 2013).

\section{CONCLUSIONS}

We have investigated the geochemistry of $\mathrm{CO}_{2}$-rich gases venting at $500 \mathrm{~m}$ b.s.l. from Kolumbo submarine volcano, which is located $7 \mathrm{~km}$ northeast of Santorini Island. The main findings are as follows:

- Gases are dominated by $\mathrm{CO}_{2}$ (>97\%), with a small air contamination probably related to sampling conditions, but are fractionated by a process of gas-water interaction reasonably related to variable fluxes of gases emitted from the different vents. This process induces a partial dissolution of gaseous $\mathrm{CO}_{2}$ in water, leading to substantial enrichment of the residual gas in those species that are much less soluble in water (i.e., $\mathrm{He}, \mathrm{H}_{2}$, $\mathrm{CO}, \mathrm{CH}_{4}$, and $\mathrm{N}_{2}$ ). This fractionation also affects the C-isotope composition of $\mathrm{CO}_{2}$.

- We modeled the gas-water interaction process $\left(\sim 220^{\circ} \mathrm{C}, \sim 50\right.$ bar and $\left.\mathrm{pH} \sim 5\right)$ and reconstructed the chemistry and $\delta^{13} \mathrm{C}_{\mathrm{CO}_{2}}$ of magmatic gases before interaction. We assess that the pristine $\mathrm{CO}_{2}$ is characterized by $\delta^{13} \mathrm{C} \sim-0.4 \%$. Combining our data with ${ }^{3} \mathrm{He} /{ }^{4} \mathrm{He}$ measurements carried out in the same gas samples by Rizzo et al. (2016) yields $\mathrm{CO}_{2} /{ }^{3} \mathrm{He} \sim 1 \times 10^{10}$. These data are in the same range as those obtained for the Santorini and Nisyros fumaroles. We argue that $\mathrm{CO}_{2}$ emitted at Kolumbo could originate from a mantle contaminated by $\mathrm{CO}_{2}$ via the decarbonation of subducting limestone.

- The $\mathrm{CH}_{4}$-isotope composition falls within the range typical of hydrothermal gases, similar to other Mediterranean hydrothermal systems (Panarea and Campi Flegrei), suggesting that it originates from mixing between thermogenic and abiotic $\mathrm{CH}_{4}$.

- We found that the $\mathrm{Hg}(0)$ concentration in Kolumbo gases ranges from $\sim 60$ to $1300 \mathrm{ng} \mathrm{m}^{-3}$. These levels are particularly high when compared to those of

\section{REFERENCES}

Allègre, C. J. (2008). Isotope Geology. Cambridge: Cambridge University Press, 512. doi: 10.1017/CBO9780511809323

Bagnato, E., Acquavita, A., Barra, M., Covelli, S., Italiano, F., Oliveri, E., et al. (2017). Hydrochemical and atmochemical mercury distribution land-based fumaroles located on Santorini Island and worldwide aerial volcanic emissions, which suggests that the magmatic activity is higher at Kolumbo than at Santorini.

- Based on geo-indicators of pressure and temperature, we calculated that magmatic gases equilibrate within the Kolumbo hydrothermal system at about $270^{\circ} \mathrm{C}$ and 116 bar.

\section{AUTHOR CONTRIBUTIONS}

AR and PN conceived the study. AR, VC, PN, PP, MM, GK, AM, and AlC participated in the collection of gas samples. AR, VC, and AnC analyzed the gas samples and elaborated the data. DL helped in figures preparation. All of the authors contributed to the preparation and editing of the final manuscript.

\section{FUNDING}

The authors acknowledge financial support from the SeaBioTech project (spider.science.strath.ac.uk/seabiotech/) funded by the European Commission within its FP7 Programme (Grant No. 311932), as well as from INGV, Sezione di Palermo, which permitted the access to analytical facilities.

\section{ACKNOWLEDGMENTS}

We thank Giuseppe Riccobono and Paolo Cosenza for providing technical support to the project and constructing the gastight sampler at INGV, Sezione di Palermo that was used to collect some of the submarine fluid samples. The officers and crew of RV AEGAEO are especially acknowledged for their valuable help during sampling. We thank INGV, Sezione di Palermo for providing analytical support, particularly Francesco Salerno and Mauro Martelli for performing analyses of gases chemistry, and Mariano Tantillo for supporting the laboratory activities involving noble-gas isotopes. We also thank Fausto Grassa, Giorgio Capasso, Ygor Oliveri, and Aldo Sollami for their help with the analyses of $\mathrm{CO}_{2}$ and $\mathrm{CH}_{4}$ isotopes in the stable-isotope laboratory. We further thank Cinzia Federico and Fausto Grassa for useful discussions that helped in the elaborative and interpretative framework. Data reported in Tables 1-3 are available by contacting the corresponding author. We thank the Chief Editor VA the Guest Associate Editor GG for handling and revising the manuscript, YT and an reviewer for suggestions that greatly improved the manuscript. English Science Editing revised the use of English in the manuscript.

over the submarine hydrothermal hot-spot sources of Panarea Island, Aeolian Archipelago. Mar. Chem. 194, 63-78. doi: 10.1016/j.marchem.2017. 04.003

Bagnato, E., Tamburello, G., Aiuppa, A., Sprovieri, M., Vougioukalakis, G. E., and Parks, M. (2013). Nea Kameni volcanic centre, Santorini (Greece). Geochem. J. 47, 437-450. doi: 10.2343/geochemj.2.0263 
Bagnato, E., Tamburello, G., Avard, G., Martinez-Cruz, M., Enrico, M., Fu, X., et al. (2014). Mercury Fluxes from volcanic and geothermal sources: an update. Geol. Soc. 410, 263-285. doi: 10.1144/SP410.2

Bernard, B. B., Brooks, J. M., and Sackett, W. M. (1978). "A geochemical model for characterization of hydrocarbon gas sources in marine sediments," in Proceedings of the Offshore Technology Conference, Houston, TX, 435-438.

Bohnhoff, M., Rische, M., Meier, T., Becker, D., Stavrakakis, G., and Harjes, H.-P. (2006). Microseismic activity in the Hellenic Volcanic Arc, Greece, with emphasis on the seismotectonic setting of the Santorini-Amorgos zone. Tectonophysics 423, 17-33. doi: 10.1016/j.tecto.2006.03.024

Brombach, T., Caliro, S., Chiodini, G., Fiebig, J., Hunziker, J., and Raco, B. (2003). Geochemical evidence for mixing of magmatic fluids with seawater, Nisyros hydrothermal system, Greece. Bull. Volcanol. 65, 505-516. doi: 10.1007/s00445003-0278- $\mathrm{x}$

Butterfield, D. A., Massoth, G. J., McDuff, R. E., Lupton, J. E., and Lilley, M. D. (1990). Geochemistry of hydrothermal fluids from Axial Seamount Hydrothermal Emissions Study Vent Field, Juan de Fuca Ridge: subseafloor boiling and subsequent fluid-rock interaction. J. Geophys. Res. 95, 12,89512,921.. doi: 10.1029/JB095iB08p12895

Caliro, S., Caracausi, A., Chiodini, G., Ditta, M., Italiano, F., Longo, M., et al. (2004). Evidence of a recent input ofmagmatic gases into the quiescent volcanic edifice of Panarea, Aeolian Islands, Italy. Geophys. Res. Lett. 31:L07619. doi: 10.1029/2003GL019359

Camilli, R., Nomikou, P., Escartín, J., Ridao, P., Mallios, A., Kilias, S. P., et al. (2015). The kallisti limnes, carbon dioxide-accumulating subsea pools. Sci. Rep. 5:12152. doi: $10.1038 /$ srep 12152

Cantner, K., Carey, S., and Nomikou, P. (2014). Integrated volcanologic and petrologic analysis of the $1650 \mathrm{AD}$ eruption of Kolumbo submarine volcano, Greece. J. Volcanol. Geothermal Res. 269, 28-43. doi: 10.1016/j.jvolgeores.2013. 10.004

Capaccioni, B., Tassi, F., Vaselli, O., Tedesco, D., and Poreda, R. (2007). Submarine gas burst at Panarea Island (southern Italy) on 3 November 2002: a magmatic versus hydrothermal episode. J. Geophys. Res. 112:B05201. doi: 10.1029/ 2006JB004359

Caracausi, A., Ditta, M., Italiano, F., Longo, M., Nuccio, P. M., Paonita, A., et al. (2005). Changes in fluid geochemistry and physico-chemical conditions of geothermal systems caused by magmatic input: the recent abrupt outgassing off the island of Panarea, Aeolian Islands, Italy. Geochim. Cosmochim. Acta 69, 3045-3059. doi: 10.1016/j.gca.2005.02.011

Carey, S., Nomikou, P., Bell, K. C., Lilley, M., Lupton, J., Roman, C., et al. (2013). $\mathrm{CO}_{2}$ degassing from hydrothermal vents at Kolumbo submarine volcano, Greece, and the accumulation of acidic crater water. Geology 41, 1035-1038. doi: $10.1130 / \mathrm{G} 34286.1$

Chiodini, G., Caliro, S., Caramanna, G., Granieri, D., Minopoli, C., Moretti, R., et al. (2006). Geochemistry of the submarine gaseous emissions of Panarea (Aeolian Islands, southern Italy): magmatic vs. hydrothermal origin and implications for volcanic surveillance. Pure Appl. Geophys. 163, 759-780. doi: 10.1007/s00024-006-0037-y

Chiodini, G., and Cioni, R. (1989). Gas geobarometry for hydrothermal systems and its application to some Italian geothermal areas. Appl. Geochem. 4, 465-472. doi: 10.1016/0883-2927(89)90004-8

Chiodini, G., Cioni, R., and Marini, L. (1993). Reactions governing the chemistry of crater fumaroles from Vulcano Island, Italy, and implications for volcanic surveillance. Appl. Geochem. 8, 357-371. doi: 10.1016/0883-2927(93)90004-Z

Chiodini, G., Cioni, R., Marini, L., and Panichi, C. (1995). Origin of the fumarolic fluids of Vulcano Island, Italy, and implications for volcanic surveillance. Bull. Volcanol. 57, 99-110. doi: 10.1007/BF00301400

Chiodini, G., and Marini, L. (1998). Hydrothermal gas equilibria: the $\mathrm{H}_{2} \mathrm{O}-\mathrm{H}_{2}-$ $\mathrm{CO}_{2}-\mathrm{CO}-\mathrm{CH}_{4}$ system. Geochim. Cosmochim. Acta 62, 2673-2687. doi: 10. 1016/S0016-7037(98)00181-1

Chiodini, G., Marini, L., and Russo, M. (2001). Geochemical evidence for the existence of hightemperature brines at Vesuvio volcano, Italy. Geochem. Cosm. Acta 65, 2129-2147. doi: 10.1016/S0016-7037(01)00583-X

Christakis, C., Polymenakou, P., Mandalakis, M., Nomikou, P., Kristoffersen, J. B., Lampridou, D., et al. (2018). Microbial community differentiation between active and inactiove sulfide chimneys of the Kolumbo submarine volcano. Hellenic Volcanic Arc. Extremophiles 22, 13-27. doi: 10.1007/s00792-0170971-x
Clark, I. D., and Fritz, P. (1997). Environmental Isotopes in Hydrogeology. Boca Raton, FL: CRC Press, 328.

Crisp, J. A. (1984). Rates of magma emplacement and volcanic output. J. Volcanol. Geotherm. Res. 20, 177-211. doi: 10.1016/0377-0273(84)90039-8

D'Amore, F., and Panichi, C. (1980). Evaluation of deep temperature of hydrothermal systems by a new gasgeothermometer. Geochim. Cosmochim. Acta 44, 549-556. doi: 10.1016/0016-7037(80)90051-4

D'Amore, F., and Truesdell, A. H. (1988). A review of solubilities and equilibrium constants of chemical reactions for gaseous species of geothermal interest. Sci. Geol. Bull. 41, 309-332. doi: 10.3406/sgeol.1988.1801

Dimitriadis, I., Karagianni, E., Panagiotopoulos, D., Papazachos, C., Hatzidimitriou, P., Bohnhoff, M., et al. (2009). Seismicity and active tectonics at Coloumbo Reef (Aegean Sea, Greece): monitoring an active volcano at Santorini Volcanic Center using a temporary seismic network. Tectonophysics 465, 136-149. doi: 10.1016/j.tecto.2008.11.005

Dimitriadis, I., Papazachos, C., Panagiotopoulos, D., Hatzidimitriou, P., Bohnhoff, M., Rische, M., et al. (2010). P and S velocity structures of the Santorini-Coloumbo volcanic system (Aegean Sea, Greece) obtained by non-linear inversion of travel times and its tectonic implications. J. Volcanol. Geothermal Res. 195, 13-30. doi: 10.1016/j.jvolgeores.2010.05.013

Dotsika, E., Poutoukis, D., Michelot, J. L., and Raco, B. (2009). Natural tracers for identifying the origin of the thermal fluids emerging along the Aegean volcanic arc (Greece): evidence of arc-type magmatic water (ATMW) participation. J. Volcanol. Geotherm. Res. 179, 19-32. doi: 10.1016/j.jvolgeores.2008.09.024

Etiope, G., and Sherwood-Lollar, B. (2013). Abiotic methane on Earth. Rev. Geophys. 51, 276-299. doi: 10.1002/rog.20011

Fernandez-Prini, R., Alvarez, J. L., and Harvey, A. H. (2003). Henry's constants and vapor-liquid distribution constants for gaseous solutes in $\mathrm{H}_{2} \mathrm{O}$ and $\mathrm{D}_{2} \mathrm{O}$ at high temperatures. J. Phys. Chem. Ref. Data 32:903. doi: 10.1063/1.1564818

Fitzgerald, W. F., and Lamborg, C. H. (2004). "Geochemistry of mercury in the environment," in Treatise on Geochemistrys: Environmental Geochemistry, Vol. 9, ed. B. S. Lollar (New York, NY: Elsevier, Inc).

Francalanci, L., Vougioukalakis, G. E., Perini, G., and Manetti, P. A. (2005). "West-East traverse along the magmatism of the South Aegean volcanic arc in the light of volcanological, chemical and isotope data. Developments in Volcanology (Amsterdam, Olanda)," in The South Aegean Active Volcanic Arc, Present Knowledge and Future Perspectives, 7, eds M. Fitykas and G. E. Vougioukalakis (Amsterdam: Elsevier), 65-111. doi: 10.1016/S1871-644X(05) 80033-6

Gennaro, M. E., Grassa, F., Martelli, M., Renzulli, A., and Rizzo, A. L. (2017). Carbon isotope composition of $\mathrm{CO}_{2}$-rich inclusions in cumulate-forming mantle minerals from Stromboli volcano (Italy). J. Volcanol. Geotherm. Res. 346, 95-103. doi: 10.1016/j.jvolgeores.2017.04.001

Giggenbach, W. F. (1975). A simple method for the collection and analysis of volcanic gas samples. Bull. Volcanol. 39, 132-145. doi: 10.1007/BF02596953

Giggenbach, W. F. (1980). Geothermal gas equilibria. Geochim. Cosmochim. Acta 44, 2021-2032. doi: 10.1016/0016-7037(80)90200-8

Giggenbach, W. F. (1987). Redox processes governing the chemistry of fumarolic gas discharges from White Island, New Zeland. Appl. Geochem. 2, 143-161. doi: 10.1016/0883-2927(87)90030-8

Giggenbach, W. F., (1991). "Geothermometry," in Isotopic and Chemical Techniques in Geothermal Exploration, Development and Use, ed. S. Arnórsson (Vienna: International Atomic Agency), 119-142.

Hilton, D. R., Fisher, T. P., and Marty, B. (2002). Noble gases and volatile recycling at subduction zones. Rev. Mineral. Geochem. 47, 319-370. doi: 10.2138/rmg. 2002.47.9

Hooft, E. E. E., Nomikou, P., Toomey, D. R., Lampridou, D., Getz, C., Christopoulou, M.-E., et al. (2017). Backarc tectonism, volcanism, and mass wasting shape seafloor morphology in the Santorini-Christiana-Amorgos region of the Hellenic Volcanic Arc. Tectonophysics 71, 396-414. doi: 10.1016/ j.tecto.2017.06.005

Hsin-Yi, W., Yuji, S., Naoto, T., Yama, T., Akizumi, I., Kentaro, T., et al. (2016). Helium and methane sources and fluxes of shallow submarine hydrothermal plumes near the Tokara Islands, Southern Japan. Sci. Rep. 6:34126. doi: 10.1038/ srep34126

Hubscher, C., Ruhnau, M., and Nomikou, P. (2015). Volcano-tectonic evolution of the polygenetic Kolumbo submarine volcano/Santorini (Aegean Sea). J. Volcanol. Geothermal Res. 291, 101-111. doi: 10.1016/j.jvolgeores.2014.12.020 
Javoy, M., and Pineau, F. (1991). The volatiles record of a "popping" rock from the mid-Atlantic ridge at $14 \mathrm{~N}$ : chemical and isotopic composition of gas trapped in the vesicles. Earth Planet. Sci. Lett. 107, 598-611. doi: 10.1016/0012-821X(91) 90104-P

Keir, R. (2010). A note on the fluxes of abiogenic methane and hydrogen from mid-ocean ridges. Geophys. Res. Lett 37:L24609. doi: 10.1029/2010GL045362

Kilias, S. P., Nomikou, P., Papanikolaou, D., Polymenakou, P. N., Godelitsas, A., Argyraki, A., et al. (2013). New insights into hydrothermal vent processes in the unique shallowsubmarine arc-volcano, Kolumbo (Santorini), Greece. Sci. Rep. 3:2421. doi: 10.1038/srep02421

Klaver, M., Carey, S., Nomikou, P., Smet, I., Godelitsas, A., and Vroon, P. (2016). A distinct source and differentiation history for Kolumbo submarine volcano, Santorini volcanic field, Aegean arc. Geochem. Geophys. Geosyst. 17, 3254-3273. doi: 10.1002/2016GC006398

Konstantinou, K. I., and Yeh, T.-Y. (2012). Stress field around the Coloumbo magma chamber, southern Aegean: Its significance for assessing volcanic and seismic hazard in Santorini. J. Geodyn. 54, 13-20. doi: 10.1016/j.jog.2011.09.003

Lamborg, C. H., Von Damm, K. L., Fitzgerald, W. F., Hammerschmidt, C. R., and Zierenberg, R. (2006). Mercury and monomethylmercury in fluids from Sea Cliff submarine hydrothermal field. Gorda Ridge Geophys. Res. Lett. 33:L17606. doi: 10.1029/2006GL026321

Lan, T. F., Sano, Y., Yang, T. F., Takahata, N., Shirai, K., and Pinti, D. (2010). Evaluating Earth degassing in subduction zones by measuring helium fluxes from the ocean floor. Earth Planet. Sci. Lett. 289, 317-322. doi: 10.1016/j.epsl. 2010.07.049

Le Pichon, X., and Angelier, J., (1979). The hellenic arc and trench system: a key to the neotectonic evolution of the eastern Mediterranean area. Tectonophysics 60 , 1-42. doi: 10.1016/0040-1951(79)90131-8

Lilley, M. D., Butterfield, D. A., Olson, E. J., Lupton, J. E., Macko, S. A., and McDuff, R. E. (1993). Anomalous $\mathrm{CH}_{4}$ and $\mathrm{NH} 4+$ concentrations at an unsedimented mid-ocean-ridge hydrothermal system. Nature 364, 45-47. doi: $10.1038 / 364045 \mathrm{a} 0$

Lupton, J., Butterfield, D., Lilley, M., Evans, L., Ko-ichi, N., Chadwick, W., et al. (2006). Submarine venting of liquid carbon dioxide on a Mariana Arc volcano. Geochem. Geophys. Geosyst. 7:Q08007. doi: 10.1029/2005GC001152

Lupton, J., Lilley, M., Butterfield, D., Evans, L., Embley, R., Massoth, G., et al. (2008). Venting of a separate $\mathrm{CO}_{2}$-rich gas phase from submarine arc volcanoes: examples from the Mariana and Tonga-Kermadec arcs. J. Geophys. Res. 113, B08S12. doi: 10.1029/2007JB005467

Lupton, J. D., Lilley, B. M., Ishibashi, J., Hey, D., and Evans, L. (1999). Gas chemistry of hydrothermal fluids along the East Pacific Rise, $5^{\circ} \mathrm{S}$ to $32^{\circ} \mathrm{S}$ (abstract). Eos Trans. 80:F1099. Fall Meet., Suppl.

Mandalakis, M., Gavriilidou, A., Polymenakou, P. N., Christakis, C., Nomikou, P., Medvecký, M., et al. (2019). $\mathrm{CO}_{2}$ vents at Kolumbo submarine volcano show microbial co-tolerance to high acidity and antibiotics. Mar. Environ. Res in press,

Mango, F. D. (2000). The origin of light hydrocarbons. Geochim. Cosmochim. Acta 51, 1549-1560. doi: 10.1016/S0016-7037(99)00389-0

Marty, B. (2012). The origins and concentrations of water, carbon, nitrogen and noble gases on Earth. Earth Planet. Sci. Lett. 31, 56-66. doi: 10.1016/j.epsl.2011. 10.040

Marty, B., and Jambon, A. (1987). C/3He in volatile flux from the solid Earth: implications for carbon dynamics. Earth Planet. Sci. Lett. 83, 16-26. doi: 10. 1016/0012-821X(87)90047-1

Mazzini, A., Svensen, H., Etiope, E., Onderdonk, N., and Banks, D. (2011). Fluid origin, gas fluxes and plumbing system in the sediment-hosted Salton Sea Geothermal System (California, USA). J. Volcanol. Geothermal Res. 205, 67-83. doi: 10.1016/j.jvolgeores.2011.05.008

McCollom, T. M., and Seewald, J. S. (2007). Abiotic synthesis of organic compounds in deep-sea hydrothermal environments. Chem. Rev. 107, 382-401. doi: $10.1021 / \mathrm{cr} 0503660$

McDermott, J. M., Seewald, J. S., German, C. R., and Sylva, S. P. (2015). Pathways for abiotic organic synthesis at submarine hydrothermal fields. PNAS 112, 7668-7672. doi: 10.1073/pnas.1506295112

McKenzie, D. (1972). Active tectonics of the Mediterranean region. Geophys. J. R. Astron. Soc. 30, 109-185. doi: 10.1111/j.1365-246X.1972.tb02351.x

Nicholls, I. A. (1971). Petrology of Santorini Volcano. Cyclades, Greece. J. Petrol. 12, 67-119. doi: 10.1093/petrology/12.1.67
Nomikou, P., Carey, S., Papanikolaou, D., Croff Bell, K., Sakellariou, D., Alexandri, M., et al. (2012). Submarine volcanoes of the Kolumbo volcanic zone NE of Santorini Caldera Greece. Glob. Planet. Change 9, 135-151. doi: 10.1016/j.gloplacha.2012.01.001

Nomikou, P., Hübscher, C., Papanikolaou, D., Farangitakis, P. G., Ruhnau, M., and Lampridou, D. (2018). Expanding extension, subsidence and lateral segmentation within the Santorini - Amorgos basins during Quaternary: implications for the 1956 Amorgos events, central - south Aegean Sea. Greece. Tectonophysics 722, 138-153. doi: 10.1016/j.tecto.2017. 10.016

Nomikou, P., Hübscher, C., Ruhnau, M., and Bejelou, K. (2016). Tectonophysics Tectono-stratigraphic evolution through successive extensional events of the Anydros Basin, hosting Kolumbo volcanic field at the Aegean. Tectonophysics 671, 202-217. doi: 10.1016/j.tecto.2016.01.021

Nomikou, P., Papanikolaou, D., Alexandri, M., Sakellariou, D., and Rousakis, G. (2013). Submarine volcanoes along the Aegean volcanic arc. Tectonophysics 59, 123-146. doi: 10.1128/AEM.01835-08

Oppenheimer, C., Fischer, T. P., and Scaillet, B. (2014). "Volcanic degassing: process and impact," in Treatise on Geochemistry, The Crust, 2nd Edn, eds H. D. Holland and K. K. Turekian (Amsterdam: Elsevier), 111-179.

Oulas, A., Polymenakou, P. N., Seshadri, R., Tripp, H. J., Mandalakis, M., PaezEspino, A. D., et al. (2015). Metagenomic investigation of the geologically unique Hellenic Volcanic Arc reveals a distinctive ecosystem with unexpected physiology. Environ. Microbiol. 18, 1122-1136. doi: 10.1111/1462-2920. 13095

Ozima, M., and Podosek, F. A. (1983). Noble Gas Geochemistry. New York, NY: Cambridge University Press.

Paonita, A., Federico, C., Bonfanti, P., Capasso, G., Inguaggiato, S., Italiano, F., et al. (2013). The episodic and abrupt geochemical changes at La Fossa fumaroles (Vulcano Island, Italy) and related constraints on the dynamics, structure, and compositions of the magmatic system. Geochim. Cosmochim. Acta 120, 158-178. doi: 10.1016/j.gca.2013.06.015

Parks, M., Biggs, J., England, P., Mather, T., Nomikou, P., Palamartchouk, K., et al. (2012). Evolution of Santorini Volcano dominated by episodic and rapid fluxes of melt from depth. Nat. Geosci. 5, 749-754. doi: 10.1038/NGEO 1562

Parks, M. M., Caliro, S., Chiodini, G., Pyle, D. M., Mather, T. A., Berlo, K., et al. (2013). Distinguishing contributions to diffuse $\mathrm{CO}_{2}$ emissions in volcanic areas from magmatic degassing and thermal decarbonation using soil gas $222 \mathrm{Rn}-$ \$13C systematics: application to Santorini volcano, Greece. Earth Planet. Sci. Lett. 377, 180-190. doi: 10.1016/j.epsl.2013.06.046

Pe-Piper, G., and Piper, D. J. W. (2007). The South Aegean active volcanic arc: relationships between magmatism and tectonics. Dev. Volcanol. 7, 113-133. doi: 10.1016/S1871-644X(05)80034-8

Proskurowski, G., Lilley, M. D., Seewald, J. S., Fruh-Green, G. L., Olson, E. J., Lupton, J. E., et al. (2008). Abiogenic hydrocarbon production at Lost City hydrothermal field. Science 319, 604-607. doi: 10.1126/science.1151194

Rayleigh, J. W. S. (1896). Theoretical considerations respecting the separation of gases by diffusion and similar processes. Philos. Mag. 42:493. doi: 10.1080/ 14786449608620944

Rizzo, A. L., Barberi, F., Carapezza, M. L., Di Piazza, A., Francalanci, L., Sortino, F., et al. (2015). New mafic magma refilling a quiescent volcano: evidence from He-Ne-Ar isotopes during the 2011-2012 unrest at Santorini, Greece. Geochem. Geophys. Geosyst. 16, 798-814. doi: 10.1002/2014GC005653

Rizzo, A. L., Caracausi, A., Chavagnac, V., Nomikou, P., Polymenakou, P. N., Mandalakis, M., et al. (2016). Kolumbo submarine volcano (Greece): an active window into the Aegean subduction system. Sci. Rep. 6:28013. doi: 10.1038/ srep 28013

Sander, R. (2015). Compilation of Henry's law constants (version 4.0) for water as solvent. Atmos. Chem. Phys. 15, 4399-4981. doi: 10.5194/acp-15-4399-2015

Sano, Y., and Marty, B. (1995). Origin of carbon in fumarolic gases from island arcs. Chem. Geol. 119, 265-274. doi: 10.1016/0009-2541(94)00097-R

Schoell, M. (1980). The hydrogen and carbon isotopic composition of methane from natural gases of various origins. Geochim. Cosmochim. Acta 44, 649-661. doi: 10.1016/0016-7037(80)90155-6

Sigurdsson, H., Carey, S., Alexandri, M., Vougioukalakis, G., Croff, K., Roman, C., et al. (2006). Marine investigations of Greece's Santorini Volcanic Field. EOS Trans. Am. Geophys. Union 87:337. doi: 10.1029/2006EO340001 
Spandler, C., Martin, L. H. J., and Pettke, T. (2012). Carbonate assimilation during magma evolution at Nisyros (Greece), South Aegean Arc: evidence from clinopyroxenite xenoliths. Lithos 146, 18-33. doi: 10.1016/j.lithos.2012.04.029

Stucker, V. K., Walker, S. L., de Ronde, C. E. J., Caratori Tontini, F., and Tsuchida, S. (2017). Hydrothermal venting at Hinepuia submarine volcano, Kermadec arc: understanding magmatic-hydrothermal fluid chemistry. Geochem. Geophys. Geosyst. 18, 3646-3661. doi: 10.1002/2016GC006713

Stull, D. R., Westrum, E. F., and Sinke, G. G. (1969). The Chemical Thermodynamics of Organic Compounds. Hoboken, NJ: Wiley.

Taran, Y., Torokhov, P., Pokrovski, G., and Shabayeva, I. (1992). Isotopic composition of mineral precipitates and free gas associated with hydrothermal vents of Piip submarine volcano, Bering Sea. Geochem. J. 26, 291-297. doi: 10.2343/geochemj.26.291

Taran, Y. A., and Giggenbach, W. F. (2003). "Geochemistry of light hydrocarbons in subduction-related volcanic and hydrothermal fluids," in Volcanic, Geothermal, and ore Forming Fluids: Rulers and Witnesses of Processes within the Earth, Vol. 10, eds S. F. Simmons and I. J. Graham (Littleton, CO: Economic Geologists Special Publication), 61-74.

Taran, Y. A., Kliger, G. A., Cienfuegos, E., and Shuykin, A. N. (2010a). Carbon and hydrogen isotopic compositions of products of open-system catalytic hydrogenation of $\mathrm{CO}_{2}$ : implications for abiogenic hydrocarbons in Earth's crust. Geochim. Cosmochim. Acta 74, 6112-6125. doi: 10.1016/j.gca.2010.08.012

Taran, Y. A., Varley, N. R., Inguaggiato, S., and Cienfuegos, E. (2010b). Geochemistry of $\mathrm{H}_{2}$ - and $\mathrm{CH}_{4}$-enriched hydrothermal fluids of Socorro Island, Revillagigedo Archipelago, Mexico. Evidence for serpentinization and abiogenic methane. Geofluids 10, 542-555. doi: 10.1111/j.1468-8123.2010. 00314.x

Tassi, F., Capaccioni, B., Caramanna, G., Cinti, D., Montegrossi, G., Pizzino, L., et al. (2009). Low-pH waters discharging from submarine vents at Panarea Island (Aeolian Islands, southern Italy) after the 2002 gas blast: origin of hydrothermal fluids and implications for volcanic surveillance. Appl. Geochem. 24, 246-254. doi: 10.1016/j.apgeochem.2008.11.015

Tassi, F., Capaccioni, B., and Vaselli, O. (2014). Compositional spatial zonation and 2005-2013 temporal evolution of the hydrothermal-magmatic fluids from the submarine fumarolic field at Panarea Island. J. Volcanol. Geothermal Res. 277, 41-50. doi: 10.1016/j.jvolgeores.2014.03.010

Tassi, F., Fiebig, J., Vaselli, O., and Nocentini, M. (2012). Origins of methane discharging from volcanic-hydrothermal, geothermal and cold emissions in Italy. Chem. Geol. 31, 36-48. doi: 10.1016/j.chemgeo.2012.03.018

Tassi, F., Vaselli, O., Papazachos, C. B., Giannini, L., Chiodini, G., Vougioukalakis, G. E., et al. (2013). Geochemical and isotopic changes in the fumarolic and submerged gas discharges during the 2011-2012 unrest at Santorini caldera (Greece). Bull. Volcanol 75, 1-15. doi: 10.1007/s00445-0130711-8

Tsunogai, U., Ishibashia, J., Wakitaa, H., Gamob, T., Watanabec, K., Kajimurac, T., et al. (1994). Peculiar features of Suiyo Seamount hydrothermal fluids, IzuBonin Arc: differences from subaerial volcanism. Earth Planet. Sci. Lett 126, 289-301. doi: 10.1016/0012-821X(94)90113-9
Varekamp, J. C., and Buseck, P. R. (1981). Mercury emissions from Mount St. Helens during September 1980. Nature 293, 555-556. doi: 10.1038/293555a0

Von Damm, K. L. (1995). "Controls on the chemistry and temporal variability of seafloor hydrothermal fluids," in Seafloor Hydrothermal Systems: Physical, Chemical, Biological, and Geological Interactions, Vol. 91, eds S. E. Humphris, R. A. Zierenberg, L. S. Mullineaux, and R. E. Thomson (Washington, DC: AGU), 222-247.

Von Damm, K. L., Oosting, S. E., Kozlowski, R., Buttermore, L. G., Colodner, D. C., Edmonds, H. N., et al. (1995). Evolution of East Pacific Rise hydrothermal vent fluids following a volcanic eruption. Nature 375, 47-50. doi: 10.1038/ $375047 \mathrm{a} 0$

Wang, D. T., Reeves, E. P., McDermott, J. M., Seewald, J. S., and One, S. (2018). Clumped isotopologue constraints on the origin of methane at seafloor hot springs. Geochim. Cosmochim. Acta 223, 141-158. doi: 10.1016/j.gca.2017. 11.030

Welhan, J. A. (1988). Origins of methane in hydrothermal systems. Chem. Geol. 71, 183-198. doi: 10.1016/0009-2541(88)90114-3

Wen, H.-Y., Sano, Y., Takahata, N., Tomonaga, Y., Ishida, A., Tanaka, K., et al. (2016). Helium and methane sources and fluxes of shallow submarine hydrothermal plumes near the Tokara Islands, Southern Japan. Sci. Rep. 6:34126. doi: 10.1038/srep34126

Whiticar, M. J. (1999). Carbon and hydrogen isotope systematics of bacterial formation and oxidation of methane. Chem. Geol. 161, 291-314. doi: 10.1016/ S0009-2541(99)00092-3

Xue-Gang, C., Hai-Yan, Z., Xiaohu, L., Chen-Tung, A., Chen, T., Frank, Y., et al. (2016). The chemical and isotopic compositions of gas discharge from shallowwater hydrothermal vents at Kueishantao, offshore northeast Taiwan. Geochem. J. 50, 341-355. doi: 10.2343/geochemj.2.0425

Yang, T. F., Lan, T. F., Hsiao-Fen, L., Ching-Chou, F., Pei-Chuan, C., ChingHua, L., et al. (2005). Gas compositions and helium isotopic ratios of fluid samples around Kueishantao, NE offshore Taiwan and its tectonic implications. Geochem. J. 39, 469-480. doi: 10.2343/geochemj.39.469

Zhang, J., Quay, P. D., and Wilbur, D. O. (1995). Carbon isotope fractionation during gas-water exchange and dissolution of $\mathrm{CO}_{2}$. Geochim. Cosmochim. Acta 59, 107-114. doi: 10.1016/0016-7037(95)91550-D

Conflict of Interest Statement: The authors declare that the research was conducted in the absence of any commercial or financial relationships that could be construed as a potential conflict of interest.

Copyright (c) 2019 Rizzo, Caracausi, Chavagnac, Nomikou, Polymenakou, Mandalakis, Kotoulas, Magoulas, Castillo, Lampridou, Marusczak and Sonke. This is an open-access article distributed under the terms of the Creative Commons Attribution License (CC BY). The use, distribution or reproduction in other forums is permitted, provided the original author(s) and the copyright owner(s) are credited and that the original publication in this journal is cited, in accordance with accepted academic practice. No use, distribution or reproduction is permitted which does not comply with these terms. 